\title{
Redox-Active Glycol Nucleic Acid (GNA) Components: Synthesis and Properties of the Ferrocenyl-GNA Nucleoside, Phosphoramidite, and Semicanonical Dinucleoside Phosphate
}

\author{
Michał Piotrowicz, Aleksandra Kowalczyk, Damian Trzybiński, Krzysztof Woźniak, \\ and Konrad Kowalski*
}

Cite This: Organometallics 2020, 39, 813-823

Read Online

ACCESS | Lلll Metrics \& More | 国 Article Recommendations | s supporting Information

ABSTRACT: Ferrocenylated glycol nucleic acid (Fc-GNA) components are rarely studied in the field of xeno nucleic acid (XNA) chemistry. As an attempt to contribute to XNA chemistry, in the present article we report a seven-step synthesis of the first semicanonical dinucleoside containing the Fc-GNA nucleoside linked to the adenosine nucleoside with a phosphodiester bond. First, the nucleoside-bearing ethynylferrocenyl moiety in the $\mathrm{C5}$ position of the uracil nucleobase was obtained. In the following steps, the nucleoside was transformed into the phosphoramidite intermediate that in turn was reacted with $N^{6}$-benzoyl- $2^{\prime}, 3^{\prime}-O$ isopropylideneadenosine to afford the target dinucleoside phosphate with $47 \%$ yield. The newly obtained Fc-GNA nucleoside is redox-active, and on the basis of this property (function), it belongs to a new class of functional GNA ( $f$ un-GNA) nucleosides. The

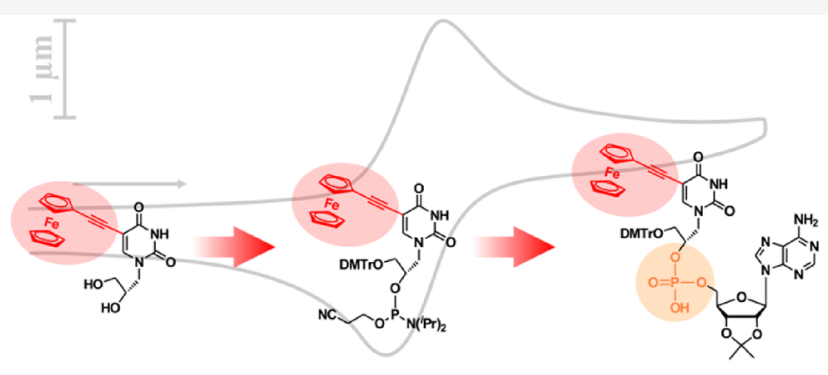
electrochemistry of the Fc-GNA nucleoside, dinucleoside phosphate, and ferrocenyl furanopyrimidone nucleoside that was obtained as an undesired byproduct of Fc-GNA nucleoside synthesis was investigated by cyclic voltammetry (CV). The CV result showed the presence of a one-electron ferrocenyl-centered redox wave in each case. The half-wave potentials of the Fc-GNA nucleoside and dinucleoside phosphate were 89 and $99 \mathrm{mV}$, respectively, against the $\mathrm{FcH} / \mathrm{FcH}^{+}$couple. Finally, the activity of the newly obtained Fc-GNA components was studied against the nontumorigenic mouse L929 and human cervix adenocarcinoma HeLa cells. The synthesized compounds showed no cytotoxic activity against the tested cell lines.

\section{INTRODUCTION}

Xeno nucleic acids (XNAs) are artificial genetic polymers containing canonical nucleobases and phosphodiester bonds but devoid of deoxy-D-ribofuranose or D-ribofuranose as backbone motifs. ${ }^{1}$ XNAs are key molecules for synthetic genetics, ${ }^{2,3}$ which is a subfield of an emerging area of synthetic biology. ${ }^{4}$ The development of specific polymerases has enabled short XNA sequences to be copied back and forth between DNA and XNA sequences. ${ }^{5,6}$ Furthermore, it has been shown that adequately engineered polymerases can copy DNA on the $\alpha$-L-threofuranose nucleic acid (TNA) template sequence and that other polymerases can catalyze the reverse reaction. ${ }^{7-10}$ In addition, natural polymerases have been successfully used to synthesize 2'-fluoro-arabino nucleic acid (FANA) on a DNA template and reversibly a DNA strand on a FANA template. ${ }^{11}$ Another study showed that short XNA sequences can act as RNA endonucleases and ligases and catalyze self-elongation by iterative incorporation of XNA nucleotides to the primer sequence. $^{12}$ TNA has been considered as a progenitor of RNA, which also vividly illustrates the importance of XNA chemistry for studies of the origin of life. ${ }^{13}$ Furthermore, peptide- conjugated phosphorodiamidate morpholino XNA oligomers have been successfully utilized as an antisense inhibitor of Burkholderia cepacia mRNA translation. ${ }^{14}$

GNA nucleosides represent a structurally simple XNA design, as they consist of 2,3-dihydroxypropyl (1,2-propanediol) chain attached to the $\mathrm{N}$ atom of the pyrimidine or purine nucleobase (structure $\mathbf{A}$ in Figure 1 with thymine as an exemplary nucleobase)..$^{15,16}$

This structural arrangement implies (a) the conformational flexibility of the GNA backbone and (b) the presence of a single stereocenter located at the $\mathrm{C}^{\prime}$ position of the 2,3dihydroxypropyl chain. Because of the presence of the single stereogenic center, the given GNA nucleoside can exist as

Received: December 17, 2019

Published: February 28, 2020 


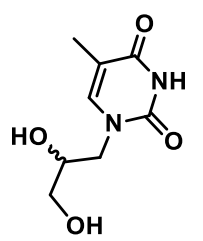

A

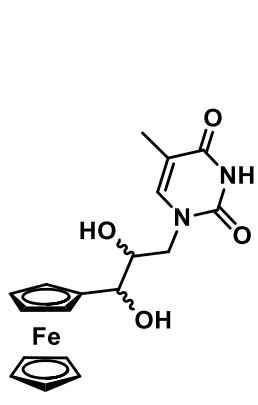

B

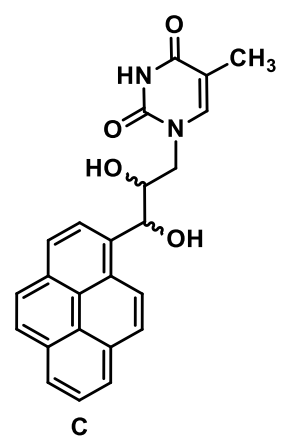

Figure 1. Structure of thymine GNA nucleoside (A), Fc-GNA nucleoside (B), and pyr-GNA (C).

either an $S$ or an $R$ enantiomer. The chemistry of GNA was studied in the 1970s, when Ueda ${ }^{17}$ and Imoto ${ }^{18,19}$ first reported the synthesis of the racemic GNA nucleosides and their oligomerization products. ${ }^{20}$ Since then, interest in the GNA synthesis has continued. ${ }^{21-25}$ Recently, Meggers and coworkers conducted extensive research on GNA chemistry $^{15,26-30}$ and crystallography. ${ }^{31,32}$ They determined X-ray crystal structures of $\mathrm{Br}$-containing and $\mathrm{Cu}$ (II)-containing selfcomplementary right-handed $(S)$-GNA duplexes. ${ }^{30-32}$ The Xray diffraction studies showed that the copper(II)-containing $(S)$-GNA duplex forms an elongated M-type helix, ${ }^{31}$ while the 5-bromocytosine-bearing duplex forms a more condensed $\mathrm{N}$ type helix. ${ }^{32}$ Both M-type and N-type $(S)$-GNA helices differ significantly from the archetypical structures of A- and B-DNA but show similarities with the structures of the hexitol nucleic $\operatorname{acid}^{33}$ and homo-DNA. ${ }^{34}$ The ability of $(R)$ - and (S)-GNA to form higher order $3 \mathrm{D}$ structures was shown by Chaput and coworkers, who synthesized two-mirror-image-containing fourway helical junctions derived from GNA. ${ }^{35}$ GNA serves as an attractive scaffold for chemical modifications. In this regard, modification of either the nucleobase or the 2,3-dihydroxypropyl chain is possible. Accordingly, Hovinen and coworkers synthesized uracil GNA phosphoramidite building blocks in which a proton in the position N3 was substituted with a nitrogen-containing lanthanide(III) chelating ligand. ${ }^{36}$ Such modified nucleosides were incorporated into the canonical DNA strands and tested by a DNA hybridization assay. The obvious disadvantage of uracil N3 position derivatization was the loss of ability to form hydrogen bonds. ${ }^{36}$ Examples of 2,3-dihydroxypropyl-modified GNA also comprise compounds in which the hydroxyl functionality in the $\mathrm{C}^{\prime}$ position was replaced with amino, ${ }^{37}$ (phosphonoethoxy)propyl, ${ }^{38}$ or carboxamide ${ }^{39}$ groups.

There is an increasing interest in ferrocenyl $(\mathrm{Fc})$ nucleobase conjugates, as these molecules show useful biological activity, and they can be used to fabricate redox-active self-assembly materials. $^{40,41}$ Thus, the subfield of Fc nucleoside chemistry originated from this area. ${ }^{42-47}$ Fc nucleosides exhibit antibacterial and anticancer activities, ${ }^{42-45}$ but the most fascinating field of their applications is the synthesis of a redox-active Fc-XNA. This task has recently been successfully achieved in the challenging synthesis of a single-stranded FcXNA oligonucleotide containing eight ferrocenyl moieties. ${ }^{48}$

Our research has been centered on the chemistry of Fcnucleobase conjugates, ${ }^{40,42,43,49,50}$ and recently, we have focused on Fc-XNA nucleoside chemistry. ${ }^{46,47}$ We conducted studies on the XNA nucleosides in which the natural deoxy-Dribofuranose backbone was replaced with a 1,1'-disubstituted ferrocene moiety. ${ }^{46}$ Furthermore, we developed an entirely new class of GNA nucleosides in which one of the hydrogens in the $\mathrm{C}^{\prime}$ position of the 2,3-dihydroxypropyl chain is substituted with the Fc moiety (see structure B in Figure 1). ${ }^{47}$ These compounds can be classified as functional GNA ( $f u n-$ GNA) nucleosides. The term fun-GNA refers to any GNA nucleoside which, apart from its inherent hydrogen-bonding ability, possesses an additional well-defined physicochemical property (function). In line with this definition, nucleoside $\mathbf{B}$ is a redox-active fun-GNA molecule. The idea of fun-GNA has also been extended to pyrenyl-GNA nucleoside C (Figure 1), which possesses luminescent function. ${ }^{51}$ The luminescent function of nucleoside $\mathbf{C}$ enabled its bioimaging by confocal microscopy in living human cervical carcinoma (HeLa) cells. ${ }^{51}$

Our interest in the modification of the basic GNA nucleoside structure $\mathbf{A}$ with a redox-active Fc moiety is ongoing. With this in mind, in the present work, the new funGNA nucleoside 4 bearing the Fc entity in the C5 position of uracil was prepared and transformed into the corresponding

Scheme 1. Synthesis of Fc-GNA Nucleoside 4 and Phosphoramidite 6

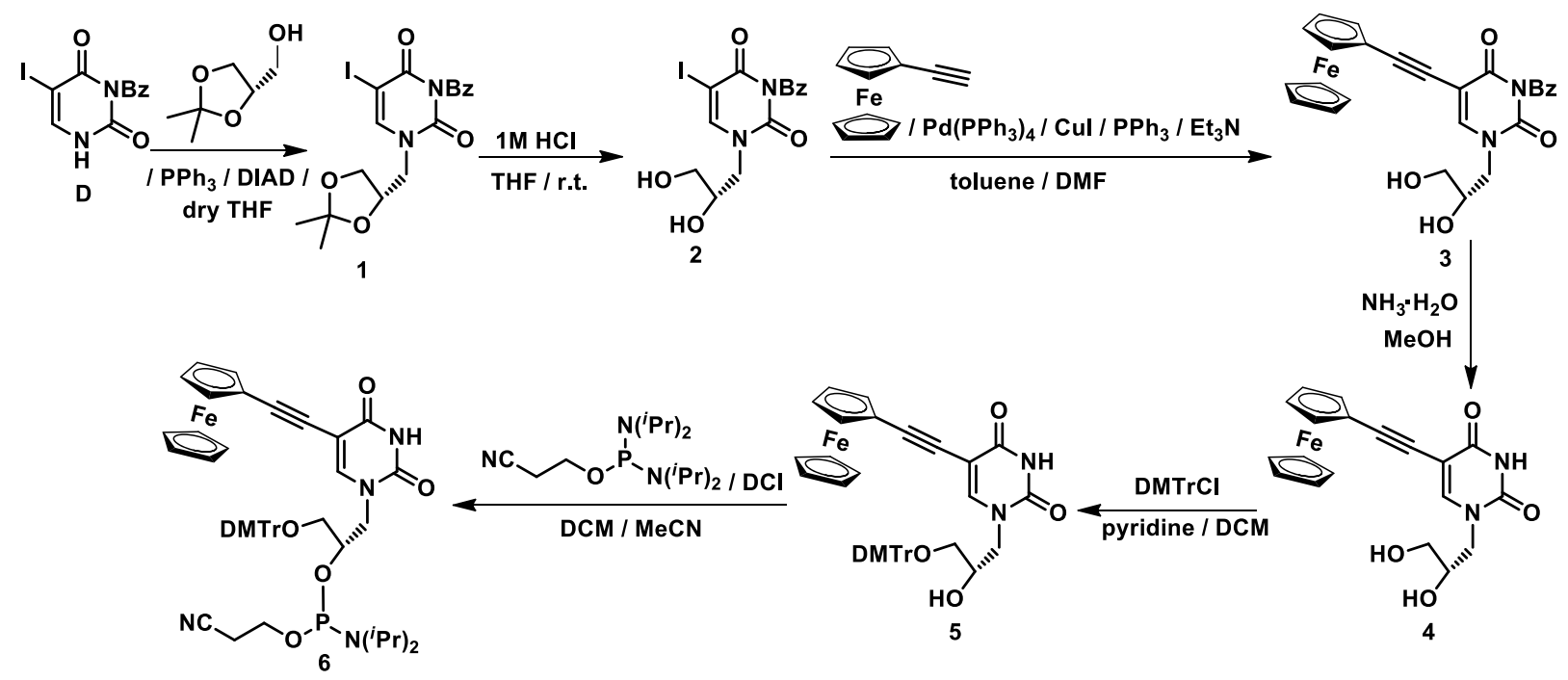


Scheme 2. Synthesis of Compounds 7, 3, and 8

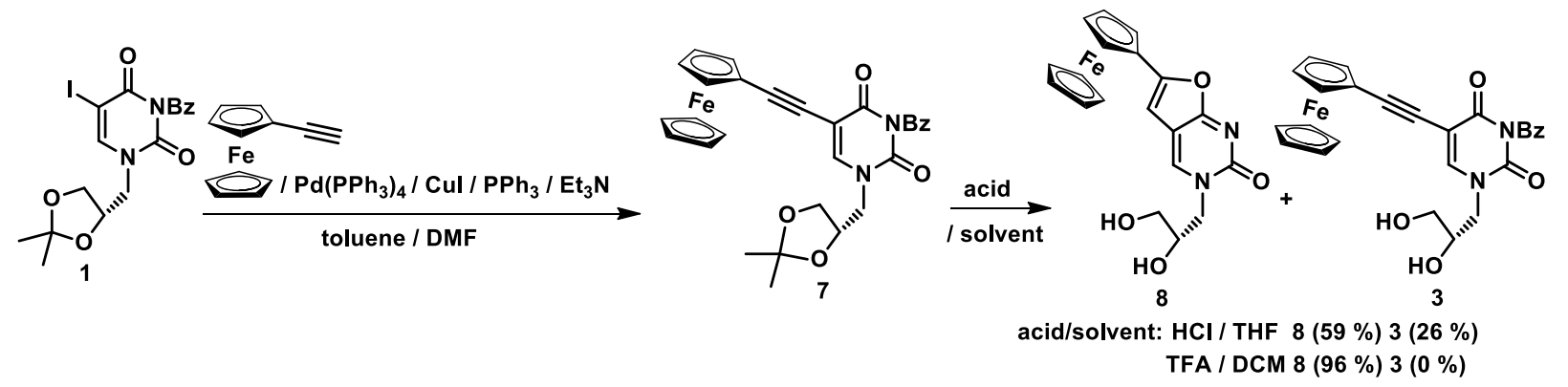

Scheme 3. Synthesis of Dinucleoside Phosphate 9
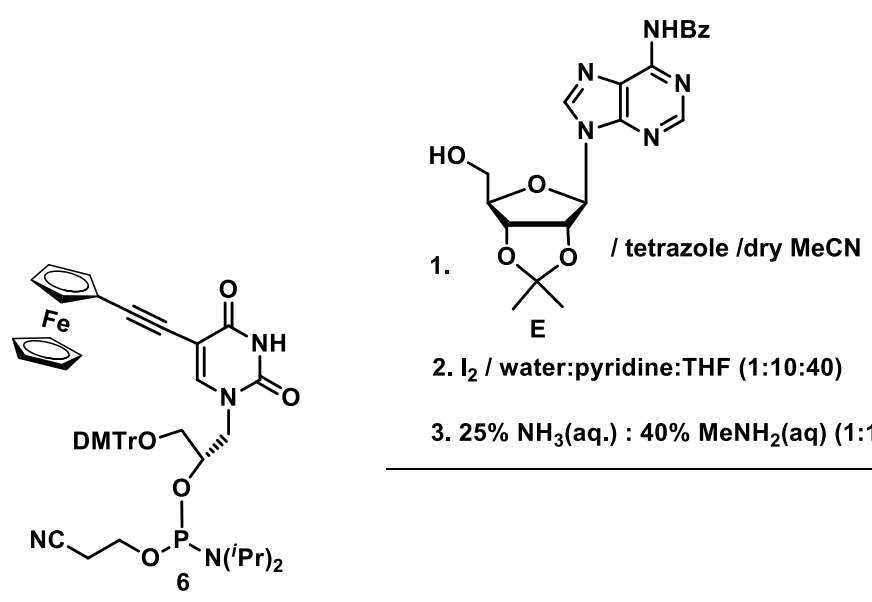

2. $I_{2} /$ water:pyridine:THF (1:10:40)

3. $25 \% \mathrm{NH}_{3}$ (aq.) : $40 \% \mathrm{MeNH}_{2}$ (aq) (1:1)

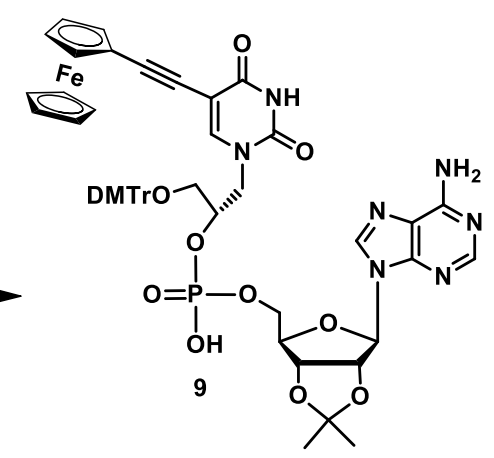

phosphoramidite derivative 6 . The synthetic usefulness of compound 6 was tested in the preparation of the semicanonical dinucleoside phosphate 9. This work also presents the electrochemical and anticancer activity studies of nucleoside 4, dinucleoside phosphate 9, and closely related furanopyrimidone derivative $\mathbf{8}$.

\section{RESULTS AND DISCUSSION}

Synthesis. The synthesis of Fc-GNA nucleoside $\mathbf{4}$ and phosphoramidite 6 was carried out as shown in Scheme 1.

First, the reaction of 5-iodo-3-benzoyluracil $(D)^{52}$ with $(S)$ 2,3-O-isopropylidene glycerol under $\mathrm{Mitsunobu}^{53}$ conditions afforded synthon 1 in $93 \%$ yield. Next, the acidic cleavage of the 2,3-O-isopropylidene group in $\mathbf{1}$ provided GNA nucleoside 2 in $96 \%$ yield. The subsequent Sonogashira cross-coupling reaction of 2 with ethynylferrocene afforded the $N^{3}$-benzoyl nucleoside 3 in $49 \%$ yield. In the following step, the $N^{3}$ benzoyl protecting group was cleaved under basic conditions to afford the target Fc-GNA nucleoside $\mathbf{4}$ in $70 \%$ yield. Nucleoside 4 was then treated with $4,4^{\prime}$-dimethoxytrityl chloride to afford $3^{\prime}$-protected compound 5 in $72 \%$ yield. Finally, tritylated nucleoside 5 was phosphitylated ${ }^{28}$ with 2 cyanoethyl $N, N, N^{\prime} N^{\prime}$-tetraisopropylphosphoradiamidite and 4,5-dicyanoimidazole (DCI) in a $\mathrm{DCM} / \mathrm{MeCN}$ solvent mixture to afford Fc-GNA phosphoramidite 6 in $67 \%$ yield. Nucleoside 4 is an air-stable, orange crystalline solid, whereas phosphoramidite $\mathbf{6}$ is an orange solid with limited stability in chloroform, dichloromethane, and dimethyl sulfoxide solvents. Compounds 1-6 were characterized by spectroscopic methods, including ${ }^{1} \mathrm{H} \mathrm{NMR},{ }^{13} \mathrm{C} \mathrm{NMR}$, and FTIR spectroscopy, mass spectrometry (MS), and elemental analysis. ${ }^{1} \mathrm{H}$
NMR and ${ }^{13} \mathrm{C}$ NMR spectra are shown in Figures S1-S5 and S9-S13, respectively.

An alternative synthetic approach was also attempted for the synthesis of intermediate 3 . It involved the Sonogashira crosscoupling reaction of the fully protected nucleoside $\mathbf{1}$ with ethynylferrocene, followed by the hydrochloric acid cleavage of the 2,3-O-isopropylidene group (Scheme 2).

The first step of the synthesis afforded compound 7 in $62 \%$ yield, while the second step resulted in the undesired furanopyrimidone product $\mathbf{8}$ in $59 \%$ yield and the target nucleoside 3 with only $26 \%$ yield. It is worth noting that the formation of furanopyrimidones as byproducts in the synthesis of some ethynylferrocene-nucleobase derivatives has been described in the literature. ${ }^{54}$ Because of the rather poor yield of compound 3, further optimization of its synthesis according to Scheme 2 was abandoned. Instead, an effort was made to increase the yield of furanopyrimidone 8 . This was justified by the fact that the electrochemical properties and cytotoxic activity of $\mathbf{8}$ were interesting in comparison with the properties of the closely related acyclic nucleoside 4 . It was found that the treatment of 7 with trifluoroacetic acid afforded compound 8 in $96 \%$ yield (Scheme 2). See Figures S6, S7, S14, and S15 in the Supporting Information for spectroscopic characterization of compounds 7 and 8 .

The last step in our synthetic endeavor was to demonstrate the usefulness of phosphoramidite $\mathbf{6}$ in internucleotide (phosphodiester) bond formation. To achieve this goal, reagents and conditions commonly used in an automated DNA synthesizer were used together with $N^{6}$-benzoyl-2', $3^{\prime}-O$ isopropylideneadenosine $(\mathrm{E})$ as the model nucleoside reactant (Scheme 3). It should be noted that the 2-cyanoethoxy 
intermediate INT (Figure S24) obtained after the coupling and oxidation step was directly used in the next step without any spectroscopic characterization. Dinucleoside phosphate 9 was obtained as an orange solid in $47 \%$ yield.

The structure of dinucleoside phosphate 9 was confirmed by spectroscopic methods and MS. The ${ }^{1} \mathrm{H} \mathrm{NMR},{ }^{13} \mathrm{C} \mathrm{NMR},{ }^{31} \mathrm{P}$ NMR, and MS spectra are shown in Figures S8, S16, S18, and S19, respectively. The ${ }^{1} \mathrm{H}$ NMR spectrum of 9 shows signals characteristic for a Fc-GNA nucleoside and the adenosine portion of the conjugate. For instance, the spectrum of 9 shows a diagnostic one-proton singlet at $11.42 \mathrm{ppm}$ for $\mathrm{N}-\mathrm{H}$ of the uracil moiety, two two-proton pseudotriplets at 4.27 and 4.44 ppm for the substituted cyclopentadienyl ligand, a five-proton singlet at $4.22 \mathrm{ppm}$ for the unsubstituted cyclopentadienyl ligand, two one-proton singlets at 8.12 and $8.49 \mathrm{ppm}$ for the adenine $\mathrm{H}-2$ and $\mathrm{H}-8$ protons, respectively, and two threeproton singlets at 1.52 and $1.28 \mathrm{ppm}$ for the $2^{\prime}, 3^{\prime}-O$ isopropylidene group. Further confirmation of the correctness of the dinucleoside phosphate 9 structure assignment was provided by ${ }^{31} \mathrm{P}$ NMR spectroscopy and mass spectrometry. The ${ }^{31} \mathrm{P}$ NMR spectrum of 9 shows a singlet at $-1.12 \mathrm{ppm}$. The high-resolution mass spectrum (TOF MS ES-) of 9 indicates a peak at an $\mathrm{m} / z$ of 1064.2670 with a calculated value of 1064.2683 for $\mathrm{C}_{53} \mathrm{H}_{51} \mathrm{~N}_{7} \mathrm{O}_{12} \mathrm{PFe}$.

Crystallographic Studies. Crystals of 1 suitable for singlecrystal X-ray diffraction analysis were obtained by slow diffusion of $n$-hexane into a saturated dichloromethane solution of $\mathbf{1}$, while crystals of $\mathbf{2}$ were grown by slow diffusion of $n$-hexane into a saturated ethanol solution of 2 . The crystal and structure refinement data are presented in Table S1. The molecular diagrams of $\mathbf{1}$ and $\mathbf{2}$ with the atom-labeling scheme are presented in Figures 2 and 3, respectively, along with selected bond lengths and angles. Complete lists of bond distances $(\AA)$, valence, and torsion angles $\left(^{\circ}\right)$ are given in Tables S2-S7.

Compounds 1 and 2 crystallize in the chiral orthorhombic space group $P 22_{1} 2_{1} 2$ with one (1) or two (2) molecule(s) of the given compound in the asymmetric unit of the crystal lattice (Figures S20 and S21). The single-crystal X-ray diffraction analysis of $\mathbf{1}$ and $\mathbf{2}$ confirms the postulated structures in which

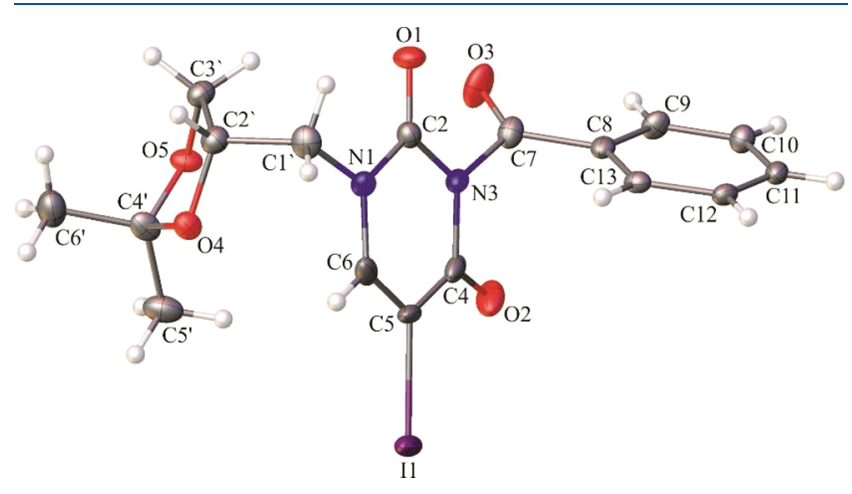

Figure 2. Molecular diagram of 1 with displacement ellipsoids at the $50 \%$ probability level. Hydrogen atoms have been omitted for clarity. Selected bond lengths $(\AA)$ and angles $\left({ }^{\circ}\right)$ : N1-C2, 1.376(6); N1C6, 1.379(6); N3-C2, 1.398(6); N3-C4, 1.402(6); C4-C5, $1.438(8) ; \mathrm{C} 5-\mathrm{C} 6,1.329(8) ; \mathrm{N} 1-\mathrm{C}^{\prime}, 1.468(6) ; \mathrm{C}^{\prime}{ }^{\prime}-\mathrm{C} 2^{\prime}$, $1.524(6) ; \mathrm{C} 2^{\prime}-\mathrm{C}^{\prime}, 1.540(7) ; \mathrm{N} 3-\mathrm{C} 7,1.471(6) ; \mathrm{C} 2-\mathrm{N} 1-\mathrm{C} 6$, 121.7(4); C2-N3-C4, 126.2(4); C4-C5-C6, 119.9(4); N1-C2$\mathrm{O} 1,124.0(4)$; O2-C4-C5, 127.9(5); $\mathrm{C} 2-\mathrm{N} 1-\mathrm{Cl}^{\prime}-\mathrm{C}^{\prime}$, 96.6(5); $\mathrm{N} 1-\mathrm{C}^{\prime}-\mathrm{C} 2^{\prime}-\mathrm{O} 4,56.9(5) ; \mathrm{C} 2-\mathrm{N} 3-\mathrm{C} 7-\mathrm{O} 3,-63.9(6)$.

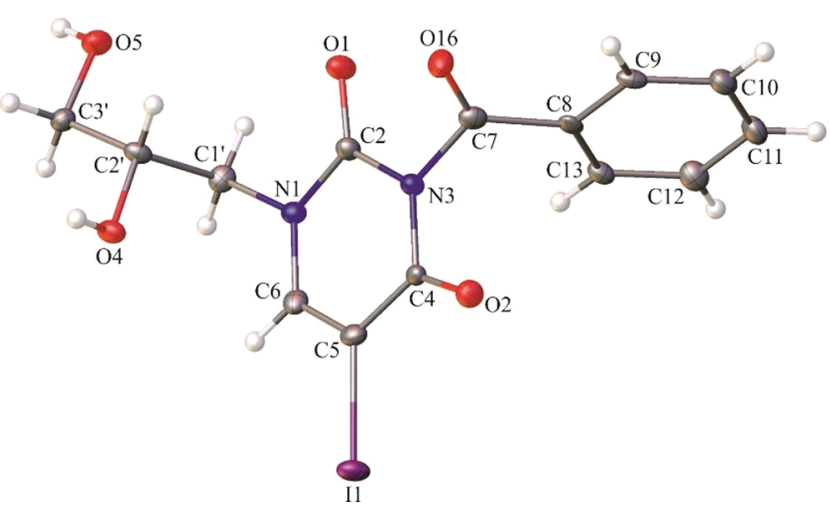

Figure 3. Molecular diagram of $\mathbf{2}$ with displacement ellipsoids at the $50 \%$ probability level. Hydrogen atoms have been omitted for clarity. Selected bond lengths $(\AA)$ and angles $\left(^{\circ}\right)$ (molecule A/molecule B): $\mathrm{N} 1-\mathrm{C} 2,1.380(8) / 1.381(8) ; \mathrm{N} 1-\mathrm{C} 6,1.366(8) / 1.371(8) ; \mathrm{N} 3-\mathrm{C} 2$, 1.395(7)/1.406(7); N3-C4, 1.406(7)/1.425(7); C4-C5, 1.430(8)/ 1.444(8); C5-C6, 1.349(9)/1.344(9); N1-C1', 1.485(8)/1.480(8); $\mathrm{C} 1^{\prime}-\mathrm{C}^{\prime}, \quad 1.521(8) / 1.532(8) ; \mathrm{C}^{\prime}-\mathrm{C}^{\prime}, 1.516(8) / 1.522(8) ; \mathrm{N} 3-$ C7, 1.484(8)/1.467(8); C2-N1-C6, 121.7(5)/121.4(5); C2-N3C4, $125.9(5) / 127.0(5)$; C4-C5-C6, $119.5(5) / 120.8(5)$; N1-C2$\mathrm{O} 1,123.5(5) / 123.9(5) ; \mathrm{O} 2-\mathrm{C} 4-\mathrm{C} 5,127.2(5) / 127.8(5) ; \mathrm{C} 2-\mathrm{N} 1-$ $\mathrm{C} 1^{\prime}-\mathrm{C} 2^{\prime},-84.0(7) / 99.0(6) ; \mathrm{N} 1-\mathrm{C}^{\prime}-\mathrm{C} 2^{\prime}-\mathrm{O} 4,-57.6(6) /-$ 60.6(6); C2-N3-C7-O3, 64.6(8)/-64.8(7).

the benzoyl protecting group is attached to the $\mathrm{N} 3$ atom of the nucleobase. The studied crystals exclusively contain enantiomers with an $S$ configuration at the stereogenic $\mathrm{C}^{\prime}$ atom. In the crystal, the carbonyl group of the benzoyl moiety in the molecule of $\mathbf{1}$ and $\mathrm{A}$ and $\mathrm{B}$ conformers of $\mathbf{2}$ is significantly twisted relative to the plane of the uracil ring. The angles between the aforementioned fragments are 64.9(2) and 69.6(2)/67.4(2) ${ }^{\circ}$ in 1 and 2 (conformer A/conformer B), respectively. This structural feature can be explained by the steric hindrance provided by the two uracil carbonyl groups placed in close proximity to the exocyclic benzoyl $\mathrm{C}=\mathrm{O}$ group. Consequently, the angle between the carbonyl and phenyl moieties within the benzoyl entity for all analyzed molecules is small (less than $20^{\circ}$ ). The 1,3-dioxolane moiety in 1 adopts a twisted-envelope conformation. The geometries of the uracil moiety in the crystallographically independent molecules A and B of $\mathbf{2}$ are essentially the same; however, their corresponding $\mathrm{N}$-bonded substituents are protruding from opposite sides of the uracil plane.

In the crystal, adjacent molecules of the investigated compounds are involved in a network of halogen and hydrogen bonds (Figures S22 and S23); however, other types of intermolecular interactions were also identified. These include weak $\mathrm{C}-\mathrm{H} \cdots \pi$ or $\pi-\pi$ and $\mathrm{C}=\mathrm{O} \cdots \pi$ contacts in $\mathbf{1}$ and 2 , respectively.

Electrochemistry. Ferrocenylated canonical oligonucleotides and nucleobases have been used as electrochemical DNA microsensors and probes. ${ }^{55-58}$ Ferrocenyl XNA oligonucleotides and nucleosides have also been a subject of in-depth electrochemical studies. ${ }^{42,46-48}$ With this in mind, we investigated Fc-GNA nucleoside 4, furanopyrimidone 8, and dinucleoside phosphate 9 by cyclic voltammetry $(\mathrm{CV})$. The $\mathrm{CV}$ measurements were carried out in $\mathrm{CH}_{2} \mathrm{Cl}_{2} /\left[\mathrm{NBu}_{4}\right]\left[\mathrm{PF}_{6}\right]$ with a platinum working electrode, a platinum-wire counter electrode, and a silver spiral as a pseudoreference electrode. The pertinent electrochemical data are presented in Table 1, and voltammograms are shown in Figures 4-6. 
Table 1. Cyclic Voltammetry Data of the Compounds at $\nu=$ $0.1 \mathrm{~V} / \mathrm{s}^{a}$

$\begin{array}{cccccc}\text { compound } & E_{\mathrm{p}, \mathrm{a}}, \mathrm{V} & E_{\mathrm{p}, \mathrm{c}} \mathrm{V} & E_{1 / 2}{ }^{0 /+b}, \mathrm{~V} & \Delta E_{\mathrm{p},}{ }^{c} \mathrm{mV} & i_{\mathrm{p}, \mathrm{a}} / i_{\mathrm{p}, \mathrm{c}}{ }^{d} \\ \mathbf{4} & 0.114 & 0.065 & 0.089 & 49 & 0.87 \\ \mathbf{8} & 0.163 & 0.102 & 0.132 & 61 & 0.97 \\ 9 & 0.134 & 0.064 & 0.099 & 70 & 1.00\end{array}$

${ }^{a}$ All data in $\mathrm{V}$ vs $\mathrm{Cp}_{2} \mathrm{Fe}^{0 /+}$ in $\mathrm{CH}_{2} \mathrm{Cl}_{2} / 0.1 \mathrm{M} \mathrm{NBu}_{4} \mathrm{PF}_{6}$ at ambient temperature. ${ }^{b}$ All half-wave potentials were calculated by the equation $E_{1 / 2}{ }^{0 /+}=\left(E_{\mathrm{p}, \mathrm{a}}+E_{\mathrm{p}, \mathrm{c}}\right) / 2 .{ }^{c}$ The differences between the anodic peak potential and the cathodic peak potential were calculated by the equation $\Delta E_{\mathrm{p}}=\left|E_{\mathrm{p}, \mathrm{a}}-E_{\mathrm{p}, \mathrm{c}}\right|{ }^{d_{\text {The }}}$ The reported $i_{\mathrm{p}, \mathrm{a}} / i_{\mathrm{p}, \mathrm{c}}$ ratios were calculated at a scan rate of $100 \mathrm{mV} / \mathrm{s}$.
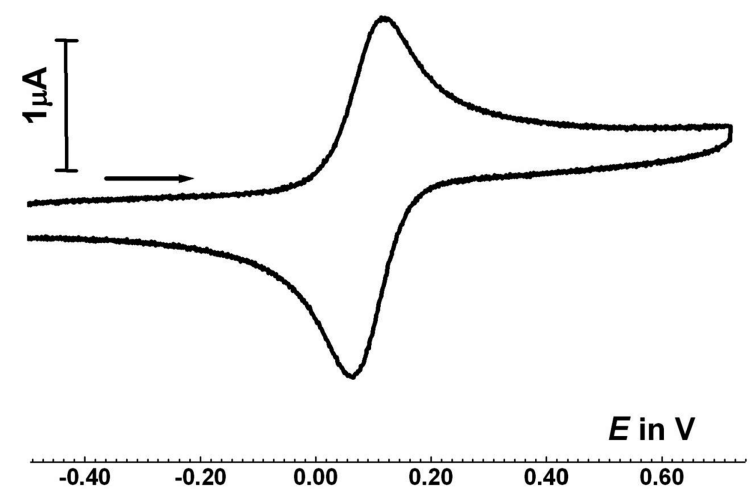

Figure 4. Cyclic voltammogram of Fc-GNA nucleoside 4 in $\mathrm{CH}_{2} \mathrm{Cl}_{2} /$ $\mathrm{NBu}_{4} \mathrm{PF}_{6}(0.1 \mathrm{M})$ at $\nu=0.1 \mathrm{~V} / \mathrm{s}$ and ambient temperature.

Compounds 4, 8, and 9 oxidize in a single one-electron process at half-wave potentials $\left(E_{1 / 2}{ }^{0 /+}\right)$ of 89,132 , and $99 \mathrm{mV}$, respectively, versus the $\mathrm{FcH} / \mathrm{FcH}^{+}$couple. The difference $\left(\Delta E_{\mathrm{p}}\right)$ between anodic $\left(E_{\mathrm{p}, \mathrm{a}}\right)$ and cathodic $\left(E_{\mathrm{p}, \mathrm{c}}\right)$ peak potentials is a good indication of the electrode kinetics (electrochemical reversibility of electrode processes). For oneelectron processes in which the forward and reverse electron transfer is fast enough to maintain equilibrium conditions, the $\Delta E_{\mathrm{p}}$ value is expected to be around $58 \mathrm{mV} .^{59}$ In strict accordance with this rule, among the three examined compounds, only furanopyrimidone $\mathbf{8}$ exhibits close to ideal diffusion-controlled one-electron redox waves characterized by a $\Delta E_{\mathrm{p}}$ value of $61 \mathrm{mV}$. Nucleoside 4 and dinucleoside phosphate 9 display one-electron redox waves characterized by peak-potential separations $\Delta E_{\mathrm{p}}$ of 49 and $70 \mathrm{mV}$, respectively. A comparison of the half-wave $E_{1 / 2}{ }^{0 /+}$ potentials in Table 1 shows that the $E_{1 / 2}{ }^{0 /+}$ value of furanopyrimidone 8 is $43 \mathrm{mV}$ higher than that of Fc-GNA nucleoside 4. This anodic shift can most likely be ascribed to the electron-withdrawing effect of the oxygen atom adjacent to the ferrocenyl moiety in 8 . On the other hand, the half-wave potential of nucleoside 4 is ca. 10 $\mathrm{mV}$ lower than that of dinucleoside phosphate 9. This indicates a minor electronic influence of the adenosine unit on "redox orbitals" of the ferrocenyl moiety in 9. To sum up, CV measurements proved the redox functionality of the Fc-GNA nucleoside and dinucleoside phosphate as well as their suitability as electrochemically active components in nucleic acid chemistry.

Cell Viability Determination. For future applications of Fc-GNA in synthetic genetics and biomaterial sciences, a routine anticancer activity assay was performed. The cytotoxicity activities of Fc-GNA nucleoside 4, furanopyrimidone 8, and dinucleoside phosphate 9 were investigated in vitro on nontumorigenic mouse murine fibroblasts L929 and human cervical epithelioid carcinoma HeLa cells by using the tetrazolium (MTT) assay. The MTT assay results are shown in Table S8. None of the assayed compounds reduced the viability of L929 and HeLa cells in comparison to control (untreated) cells upon $24 \mathrm{~h}$ treatment in the tested concentration range. This is a desirable effect, as it potentially allows for the use of $\mathbf{4}$ and $\mathbf{9}$ as XNA components in living cells and tissues without any toxic side effects.

\section{CONCLUSION}

The GNA is the simplest member from the XNA family. It is considered as one of the possible predecessors of the RNA world in the early stages of life evolution on earth. Presently, GNA has become an increasingly important alternative to canonical nucleic acids with possible applications in synthetic biology and medicinal and materials chemistry. It is therefore an attractive scaffold for chemical modifications. With this background, in the present work, we designed and synthesized functional Fc-GNA components (nucleoside and phosphor-

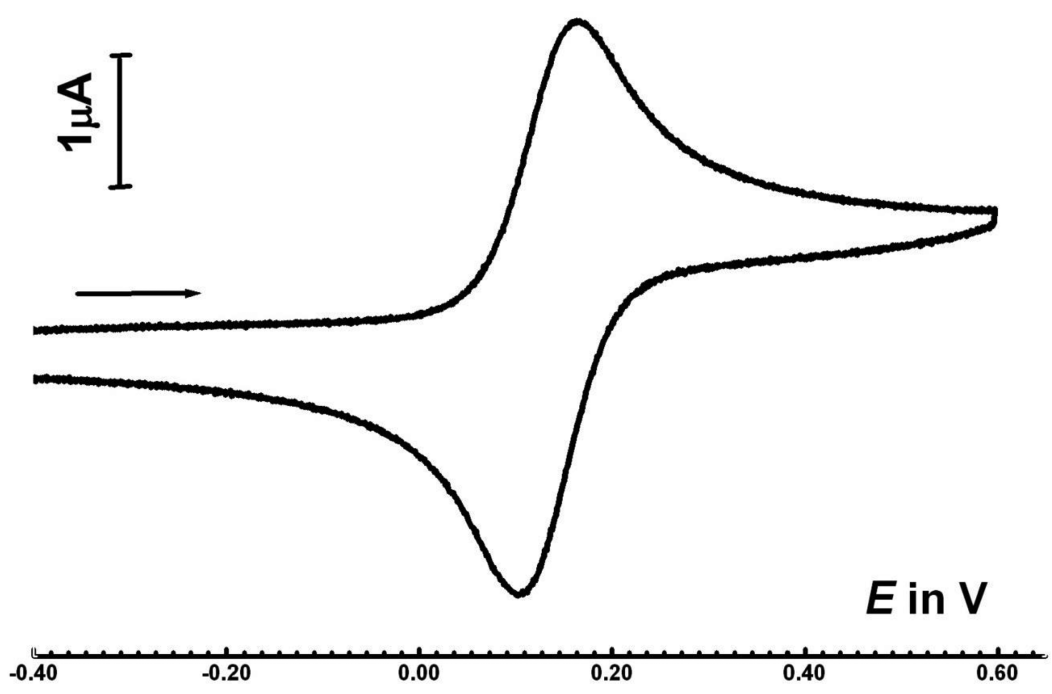

Figure 5. Cyclic voltammogram of furanopyrimidone 8 in $\mathrm{CH}_{2} \mathrm{Cl}_{2} / \mathrm{NBu}_{4} \mathrm{PF}_{6}(0.1 \mathrm{M})$ at $\nu=0.1 \mathrm{~V} / \mathrm{s}$ and ambient temperature. 


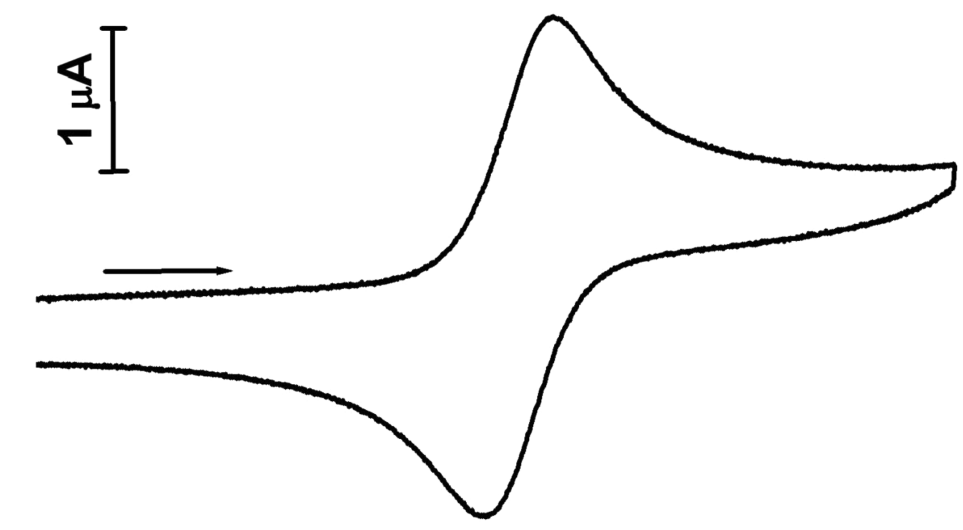

$E$ in V

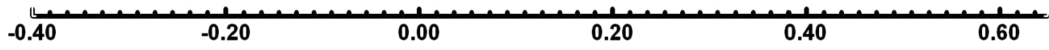

Figure 6. Cyclic voltammogram of dinucleotide 9 in $\mathrm{CH}_{2} \mathrm{Cl}_{2} / \mathrm{NBu}_{4} \mathrm{PF}_{6}(0.1 \mathrm{M})$ at $\nu=0.1 \mathrm{~V} / \mathrm{s}$ and ambient temperature.

amidite) with a function pertaining to redox activity. Successful use of the Fc-GNA phosphoramidite in semicanonical dinucleoside phosphate synthesis shows its potential as a building block in GNA chemistry. Neither Fc-GNA components nor the dinucleoside phosphate has shown cytotoxic activity against mammalian cells in vitro; this is a good prognosis regarding their safe use in living systems. Another possible application of the Fc-GNA components is the synthesis of redox-active self-assembly "molecular wires". In summary, our study proved that a Fc-GNA nucleoside can serve as a redox-active building block in the field of artificial nucleic acid chemistry. Investigations are currently ongoing to further develop the chemistry and the biology of Fc-GNA components and to use them in oligo Fc-GNA synthesis.

\section{EXPERIMENTAL SECTION}

General Considerations. All preparations were carried out using standard Schlenk techniques. Chromatographic separations were carried out using silica gel 60 (Merck, 230-400 mesh ASTM) and preparative TLC plates (Merck Silica gel 60). THF was distilled over $\mathrm{Na} /$ benzophenone prior to use. Other solvents were of reagent grade and were used without prior purification. The NMR spectra were recorded on a Bruker AV600 Kryo $(600 \mathrm{MHz})$ spectrometer. Chemical shifts $\delta$ are reported in ppm using residual DMSO as reference $\left({ }^{1} \mathrm{H} \delta 2.50 \mathrm{ppm}\right.$ and $\left.{ }^{13} \mathrm{C} \delta 39.70 \mathrm{ppm}\right)$. Mass spectra were recorded using the electron impact MS method on a Finnigan MAT 95 mass spectrometer and the electrospray ionization MS method on a Synapt G2-Si mass spectrometer (Waters). High-resolution mass spectrometry (HRMS) measurements were performed using a Synapt G2-Si mass spectrometer (Waters) equipped with an ESI source and quadrupole time-of-flight mass analyzer. The mass spectrometer was operated in the positive and negative ion detection modes. The measurement was performed with the capillary voltage set to $2.7 \mathrm{kV}$ and sampling cone to $20 \mathrm{~V}$. The source temperature was $110^{\circ} \mathrm{C}$. The results of the measurements were processed using the MassLynx 4.1 software (Waters) incorporated in the instrument. IR spectra were recorded on a FTIR Nexus Nicolet apparatus. Microanalyses were performed by the Analytical Services of the Polish Academy of the Sciences (Łódź).

X-ray Structure Analysis. Good-quality single-crystals of $\mathbf{1}$ and $\mathbf{2}$ were selected for the X-ray diffraction experiments at $T=100(2) \mathrm{K}$. Diffraction data were collected on an Agilent Technologies SuperNova Double Source diffractometer with $\mathrm{Cu} \mathrm{K} \alpha(\lambda=1.54184 \AA)$ radiation, using CrysAlis RED software. ${ }^{60}$ In both cases, the analytical numerical absorption correction using a multifaceted crystal model based on expressions derived by Clark and Reid ${ }^{61}$ implemented in SCALE3 ABSPACK scaling algorithm was applied. ${ }^{60}$ The structural determination procedure was carried out using the SHELX package. ${ }^{62}$ The structures were solved with direct methods, and successive leastsquares refinement was then carried out on the basis of the full-matrix least-squares method on $F^{2}$ using the SHELXT program. ${ }^{62}$ The hydroxyl $\mathrm{H}$ atoms in the case of 2 were located on the Fourier difference electron density map and refined with the $\mathrm{O}-\mathrm{H}$ bond lengths restrained to $0.85 \AA$, with $U_{\text {iso }}(\mathrm{H})=1.5 U_{\text {eq }}(\mathrm{O})$. The remaining $\mathrm{H}$ atoms were positioned geometrically, with the $\mathrm{C}-\mathrm{H}$ bond lengths equal to $0.93,0.96,0.97$, and $0.98 \AA$ for the aromatic, methyl, methylene, and methine $\mathrm{H}$ atoms, respectively, and constrained to ride on their parent atoms with $U_{\text {iso }}(\mathrm{H})=x U_{\mathrm{eq}}(\mathrm{C})$, where $x=1.2$ for the aromatic, methylene, and methine $\mathrm{H}$ atoms, and $x=1.5$ for the methyl $\mathrm{H}$ atoms. The molecular interactions in crystals have been identified using the PLATON program. ${ }^{63}$ The figures for this publication were prepared using Olex2, Mercury, and ORTEP-3 programs. $^{64-66}$

Cyclic Voltammetry. Electrochemical work was performed on a Princeton Applied Research VersaStat3 potentiostat in a home-built vacuum-tight one-compartment cell using a Pt electrode as the working electrode, a platinum spiral as the counter electrode, and a silver spiral as the pseudoreference electrode. The spiral-shaped electrodes were welded to Vycon wire and sealed into a glass tube. Counter and reference electrodes were introduced into the cell through appropriate fittings in the side wall and sealed using a Quickfit screw. $\mathrm{CH}_{2} \mathrm{Cl}_{2}$ for electrochemical use was distilled from $\mathrm{CaH}_{2}$, deoxygenated by saturation with argon, and briefly stored over molecular sieves. Potential calibration was performed by adding decamethylferrocene $\left(E_{1 / 2}=-0.550 \mathrm{~V}\right.$ vs $\left.\mathrm{Cp}_{2} \mathrm{Fe}^{0 /+}\right)$ as an internal standard. The amount of the reference compound added was adjusted until the peak currents of its redox features were comparable to those of the analyte. Potentials are reported against the ferrocene/ ferrocenium couple.

Cell Viability Determination. The three compounds 4, 8, and 9 were tested for their effect on cell viability by using a previously described MTT reduction assay. ${ }^{67}$ Human tumor HeLa cells (ATTC-CCL-2) and murine fibroblasts L929 cells (ATCC CCL1) were cultured as a monolayer in Dulbecco's Modified Eagle's Medium (DMEM) supplemented with $10 \%$ fetal bovine serum (FBS), $100 \mathrm{U} / \mathrm{mL}$ penicillin, and $100 \mu \mathrm{g} / \mathrm{mL}$ streptomycin. The cell cultures were incubated at $37{ }^{\circ} \mathrm{C}$ in a humidified atmosphere with $5 \% \mathrm{CO}_{2}$. For the determination of cell viability, the cells were plated in 96-well microplates at a density of $1 \times 10^{4}$ cells/well according to the International Standard (ISO 10993:2009, Biological evaluation of medical devices-Part 5: Tests for in vitro cytotoxicity). After overnight incubation, the tested compounds were added in twofold 
dilutions. Because of the different solubilities and precipitations in the culture medium, different concentration ranges were used: $31-2000$ $\mu \mathrm{M}$ for $4,0.31-20 \mu \mathrm{M}$ for 8 , and 3.1-200 $\mu \mathrm{M}$ for 9. All compounds were dissolved in DMSO, and the maximum concentration on the plate did not exceed $1 \%$ DMSO in the culture medium and had no significant influence on cell viability. After $24 \mathrm{~h}$ of incubation, $50 \mu \mathrm{L}$ of $1 \mathrm{mg} / \mathrm{mL}$ MTT (3-(4,5-dimethylthiazol-2-yl)-2,5-diphenyltetrazoliumbromide) was added, and the plates were incubated for a further $2 \mathrm{~h}$ at $37{ }^{\circ} \mathrm{C}$ in $5 \% \mathrm{CO}_{2}$. Then, formazan crystals were solubilized in $100 \mu \mathrm{L}$ of DMSO and quantified by spectrophotometric measurement at $570 \mathrm{~nm}$ by using a SpectraMax i3Multi-Mode Platform instrument (Molecular Devices). The results of the experiments are shown as mean arithmetic values from three independent experiments, and the percentage of viability inhibition was calculated in comparison with the untreated controls. $\mathrm{IC}_{50}$ values (drug concentration that inhibits cell viability by $50 \%$ ) were calculated with GraphPad Prism 7 software using nonlinear regression.

Synthesis of 1. 5-Iodo-3-benzoyluracil $(1230 \mathrm{mg}, 3.60 \mathrm{mmol}, 1.2$ equiv), (S)-2,3-O-isopropylideneglycerol $(370 \mu \mathrm{L}, 3.00 \mathrm{mmol}, 1.0$ equiv), triphenylphosphine (1180 mg, $4.50 \mathrm{mmol}, 1.5$ equiv), and dry tetrahydrofuran $(15 \mathrm{~mL})$ were placed in a Schlenk flask. The reaction mixture was cooled to $0{ }^{\circ} \mathrm{C}$, and DIAD $(890 \mu \mathrm{L}, 4.50 \mathrm{mmol}, 1.5$ equiv) was added dropwise. After it was warmed to ambient temperature, the reaction mixture was stirred overnight. All volatile materials were removed under reduced pressure. The residue was subjected to column chromatography on $\mathrm{SiO}_{2}$ (n-hexane/EtOAc; 3/1 $\mathrm{v} / \mathrm{v}$ ). Chromatographically purified $\mathbf{1}$ was crystallized from a mixture of dichloromethane $/ n$-hexane to afford an analytically pure sample as a colorless solid in $93 \%(1280 \mathrm{mg})$ yield.

${ }^{1} \mathrm{H}$ NMR (600 MHz, DMSO- $\left.d_{6}\right): \delta 8.34(\mathrm{~s}, 1 \mathrm{H}, \mathrm{H}-6$ uracil), 7.97 $\left(\mathrm{d}, J_{\mathrm{H}, \mathrm{H}}=7.2 \mathrm{~Hz}, 2 \mathrm{H}, o-\mathrm{H}\right.$ benzoyl), $7.79\left(\mathrm{t}, J_{\mathrm{H}, \mathrm{H}}=7.2 \mathrm{~Hz}, 1 \mathrm{H}, p-\mathrm{H}\right.$ benzoyl), $7.60\left(\mathrm{t}, J_{\mathrm{H}, \mathrm{H}}=7.2 \mathrm{~Hz}, 2 \mathrm{H}, m-\mathrm{H}\right.$ benzoyl $), 4.35\left(\mathrm{~m}, 1 \mathrm{H}, 2^{\prime}\right.$ $\mathrm{CH}), 4.02\left(\mathrm{dd}, J_{\mathrm{H}, \mathrm{H}}=8.4,6.6 \mathrm{~Hz}, 1 \mathrm{H}, 1^{\prime}-\mathrm{CH}_{2}\right), 3.91\left(\mathrm{~m}, 2 \mathrm{H}, 3^{\prime}-\right.$ $\left.\mathrm{CH}_{2}\right), 3.716\left(\mathrm{dd}, J_{\mathrm{H}, \mathrm{H}}=9.0,4.8 \mathrm{~Hz}, 1^{\prime}-\mathrm{CH}_{2}\right), 1.36\left(\mathrm{~s}, 3 \mathrm{H}, \mathrm{CH}_{3}\right), 1.27$ $\left(\mathrm{s}, 3 \mathrm{H}, \mathrm{CH}_{3}\right) \cdot{ }^{13} \mathrm{C}\left\{{ }^{1} \mathrm{H}\right\}$ NMR $\left(150 \mathrm{MHz}, \mathrm{DMSO}-d_{6}\right): \delta 168.7,159.5$, 151.4, 149.6, 135.6, 130.6, 130.4, 129.5, 108.9, 73.0, 66.8, 65.9, 50.0, 26.4, 25.0 ppm. MS (EI, $70 \mathrm{eV}): \mathrm{m} / z 456\left(\mathrm{M}^{+}\right), 105\left(\mathrm{C}_{7} \mathrm{H}_{5} \mathrm{O}^{+}\right)$. FTIR $\left(\mathrm{KBr} \nu\left[\mathrm{cm}^{-1}\right]\right): 3069,2984,2927,1750(\mathrm{C}=\mathrm{O}), 1701(\mathrm{C}=\mathrm{O})$, $1662(\mathrm{C}=\mathrm{O}), 1611(\mathrm{C}=\mathrm{O}), 1418,1238$. Anal. Calcd for $\mathrm{C}_{17} \mathrm{H}_{17} \mathrm{~N}_{2} \mathrm{O}_{5} \mathrm{I}: \mathrm{C}, 44.75 ; \mathrm{H}, 3.76 ; \mathrm{N}, 6.14$. Found: C, 44.97; H, 3.92; N, 6.27 .

Synthesis of 2. Hydrochloric acid $(1.0 \mathrm{M}, 60 \mathrm{~mL})$ was added to a stirred solution of 1 ( $1250 \mathrm{mg}, 4.00 \mathrm{mmol}, 1.0$ equiv) in THF (60 $\mathrm{mL}$ ). The resulting reaction mixture was stirred at ambient temperature overnight. THF was then evaporated under reduced pressure, and the residue was extracted with a dichloromethane/ methanol mixture $(20 / 1 ; \mathrm{v} / \mathrm{v})$. The organic layer was separated in a separation funnel and transferred into a round-bottom flask, where compound 2 precipitated as a colorless solid. The precipitated material was separated by filtration, washed with diethyl ether, and dried under reduced pressure. Compound 2 was obtained in $96 \%$ (1610 mg) yield.

${ }^{1} \mathrm{H}$ NMR $\left(600 \mathrm{MHz}\right.$, DMSO- $\left.d_{6}\right): \delta 8.27(\mathrm{~s}, 1 \mathrm{H}, \mathrm{H}-6$ uracil), 7.98 (dd, $J_{\mathrm{H}, \mathrm{H}}=7.8,1.2 \mathrm{~Hz}, 2 \mathrm{H}, o-\mathrm{H}$ benzoyl), $7.79\left(\mathrm{t}, J_{\mathrm{H}, \mathrm{H}}=7.8 \mathrm{~Hz}, 1 \mathrm{H}\right.$, $p$ - $\mathrm{H}$ benzoyl), $7.60\left(\mathrm{t}, J_{\mathrm{H}, \mathrm{H}}=7.8 \mathrm{~Hz}, 2 \mathrm{H}, m-\mathrm{H}\right.$ benzoyl $), 5.18\left(\mathrm{~d}, J_{\mathrm{H}, \mathrm{H}}\right.$ $\left.=5.4 \mathrm{~Hz}, 1 \mathrm{H}, 2^{\prime}-\mathrm{OH}\right), 4.72\left(\mathrm{t}, J_{\mathrm{H}, \mathrm{H}}=5.4 \mathrm{~Hz}, 1 \mathrm{H}, 3^{\prime}-\mathrm{OH}\right), 3.99(\mathrm{dd}$, $\left.J_{\mathrm{H}, \mathrm{H}}=13.5,3.0 \mathrm{~Hz}, 1 \mathrm{H}, 1^{\prime}-\mathrm{CH}_{2}\right), 3.72\left(\mathrm{~m}, 1 \mathrm{H}, 2^{\prime}-\mathrm{CH}\right), 3.56\left(\mathrm{dd}, J_{\mathrm{H}, \mathrm{H}}\right.$ $\left.=13.5,9.0 \mathrm{~Hz}, 1 \mathrm{H}, 1^{\prime}-\mathrm{CH}_{2}\right), 3.40\left(\mathrm{dt}, J_{\mathrm{H}, \mathrm{H}}=10.8,5.4 \mathrm{~Hz}, 1 \mathrm{H}, 3^{\prime}-\right.$ $\left.\mathrm{CH}_{2}\right), 3.31\left(\mathrm{dt}, J_{\mathrm{H}, \mathrm{H}}=10.8,5.4 \mathrm{~Hz}, 1 \mathrm{H}, 3^{\prime}-\mathrm{CH}_{2}\right) \mathrm{ppm} .{ }^{13} \mathrm{C}\left\{{ }^{1} \mathrm{H}\right\} \mathrm{NMR}$ $\left(150 \mathrm{MHz}, \mathrm{DMSO}-d_{6}\right): \delta 168.8,159.7,151.9,149.3,135.5,130.7$, 130.3, 129.4, 68.6, 65.9, 63.5, 52.0 ppm. MS (EI, $70 \mathrm{eV}): \mathrm{m} / z 416$ $\left(\mathrm{M}^{+}\right), 238\left(5\right.$-iodoracil $\left.{ }^{+}\right), 105\left(\mathrm{C}_{7} \mathrm{H}_{5} \mathrm{O}^{+}\right)$. FTIR $\left(\mathrm{KBr} \nu\left[\mathrm{cm}^{-1}\right]\right)$ : 3543, 3475, 3253, 3089, 3059, 2949, 2914, 2878, 1743 (C=O), 1695 $(\mathrm{C}=\mathrm{O}), 1654(\mathrm{C}=\mathrm{O}), 1612(\mathrm{C}=\mathrm{O}), 1596,1420,1026$. Anal. Calcd for $\mathrm{C}_{14} \mathrm{H}_{13} \mathrm{~N}_{2} \mathrm{O}_{5} \mathrm{I}$ : C, 40.40; H, 3.15; N, 6.73. Found: C, 40.34; $\mathrm{H}, 3.05$; N, 6.71 .

Synthesis of 3. A deoxygenated mixture of $2(832 \mathrm{mg}, 2.00 \mathrm{mmol}$, 1.0 equiv), ethynylferrocene ( $1260 \mathrm{mg}, 6.00 \mathrm{mmol}, 3.0$ equiv), triphenylphosphine (52 $\mathrm{mg}, 0.20 \mathrm{mmol}, 0.1$ equiv), triethylamine (560 $\mu \mathrm{L}, 4.00 \mathrm{mmol}, 2.0$ equiv), copper(I) iodide (762 mg, 4.00 mmol, 2.0 equiv), and tetrakis(triphenylphosphane)palladium(0) (231 $\mathrm{mg}, 0.20 \mathrm{mmol}, 0.1$ equiv) in DMF $(5 \mathrm{~mL})$ was stirred at ambient temperature overnight. All volatile materials were evaporated under reduced pressure. The residue was subjected to column chromatography on $\mathrm{SiO}_{2}$ ( $n$-hexane/EtOAc; $1 / 2 \mathrm{v} / \mathrm{v}$ ). Chromatographically purified 3 was crystallized from a mixture of dichloromethane $/ n$-hexane to afford an analytically pure sample as an orange crystalline solid in $49 \%(488 \mathrm{mg})$ yield.

${ }^{1} \mathrm{H}$ NMR (600 MHz, DMSO- $\left.d_{6}\right): \delta 8.19(\mathrm{~s}, 1 \mathrm{H}, \mathrm{H}-6$ uracil), 8.03 $\left(\mathrm{dd}, J_{\mathrm{H}, \mathrm{H}}=7.8,1.2 \mathrm{~Hz}, 2 \mathrm{H}, o-\mathrm{H}\right.$ benzoyl $), 7.81\left(\mathrm{t}, J_{\mathrm{H}, \mathrm{H}}=7.8 \mathrm{~Hz}, 1 \mathrm{H}\right.$, $p$ - $\mathrm{H}$ benzoyl), $7.62\left(\mathrm{t}, J_{\mathrm{H}, \mathrm{H}}=7.8 \mathrm{~Hz}, 2 \mathrm{H}, m-\mathrm{H}\right.$ benzoyl), $5.27\left(\mathrm{~d}, J_{\mathrm{H}, \mathrm{H}}\right.$ $\left.=5.4 \mathrm{~Hz}, 1 \mathrm{H}, 2^{\prime}-\mathrm{OH}\right), 4.77\left(\mathrm{t}, J_{\mathrm{H}, \mathrm{H}}=5.4 \mathrm{~Hz}, 1 \mathrm{H}, 3^{\prime}-\mathrm{OH}\right), 4.52(\mathrm{pt}$, $\left.J_{\mathrm{H}, \mathrm{H}}=1.8 \mathrm{~Hz}, 2 \mathrm{H}, \mathrm{C}_{5} \mathrm{H}_{4}\right), 4.31\left(\mathrm{pt}, J_{\mathrm{H}, \mathrm{H}}=1.8 \mathrm{~Hz}, 2 \mathrm{H}, \mathrm{C}_{5} \mathrm{H}_{4}\right), 4.25(\mathrm{~s}$, $\left.5 \mathrm{H}, \mathrm{C}_{5} \mathrm{H}_{5}\right), 4.04\left(\mathrm{dd}, J_{\mathrm{H}, \mathrm{H}}=13.8,3.0 \mathrm{~Hz}, 1 \mathrm{H}, 1^{\prime}-\mathrm{CH}_{2}\right), 3.75(\mathrm{~m}, 1 \mathrm{H}$, $\left.2^{\prime}-\mathrm{CH}\right), 3.58\left(\mathrm{dd}, J_{\mathrm{H}, \mathrm{H}}=13.8,9.0 \mathrm{~Hz}, 1 \mathrm{H}, 1^{\prime}-\mathrm{CH}_{2}\right), 3.43\left(\mathrm{dt}, J_{\mathrm{H}, \mathrm{H}}=\right.$ $\left.10.8,5.4 \mathrm{~Hz}, 1 \mathrm{H}, 3^{\prime}-\mathrm{CH}_{2}\right), 3.34\left(\mathrm{dt}, J_{\mathrm{H}, \mathrm{H}}=10.8,5.4 \mathrm{~Hz}, 1 \mathrm{H}, 3^{\prime}-\mathrm{CH}_{2}\right)$ ppm. ${ }^{13} \mathrm{C}\left\{{ }^{1} \mathrm{H}\right\}$ NMR $\left(150 \mathrm{MHz}\right.$, DMSO- $\left.d_{6}\right): \delta 168.9,160.9,150.2$, 148.7, 135.6, 130.9, 130.4, 129.5, 97.3, 91.8, 76.8, 71.17, 71.13, 69.8, 69.0, 68.6, 63.9, 63.6, 52.3. MS (EI, $70 \mathrm{eV}): m / z=498\left(\mathrm{M}^{+}\right), 394$ $\left(\mathrm{MH}^{+}-\mathrm{C}_{7} \mathrm{H}_{5} \mathrm{O}\right), 105\left(\mathrm{C}_{7} \mathrm{H}_{5} \mathrm{O}^{+}\right)$. FTIR $\left(\mathrm{KBr} \nu\left[\mathrm{cm}^{-1}\right]\right): 3401,3083$, 2925, 2872, $1750(\mathrm{C}=\mathrm{O}), 1701(\mathrm{C}=\mathrm{O}), 1654(\mathrm{C}=\mathrm{O}), 1625(\mathrm{C}=$ O), 1430, 1233. Anal. Calcd for $\mathrm{C}_{26} \mathrm{H}_{22} \mathrm{~N}_{2} \mathrm{O}_{5} \mathrm{Fe}: \mathrm{C}, 62.67 ; \mathrm{H}, 4.45 ; \mathrm{N}$, 5.62. Found: C, $62.68 ; \mathrm{H}, 4.75 ; \mathrm{N}, 5.52$.

Synthesis of 4 . Aqueous ammonia $(25 \%, 2 \mathrm{~mL})$ was added to a stirred solution of $\mathrm{N}^{3}$-benzoyl-protected nucleoside 3 in methanol (2 $\mathrm{mL}$ ). The reaction mixture was stirred at ambient temperature for $2 \mathrm{~h}$. After evaporation of all volatiles under reduced pressure, the remaining solid was subjected to column chromatography on $\mathrm{SiO}_{2}$ (dichloromethane/methanol $100 / 1$ to $25 / 1 \mathrm{v} / \mathrm{v}$ ). Chromatographically purified 4 was crystallized from a dichloromethane $/ n$-hexane mixture to afford an analytically pure sample as an orange crystalline solid in $70 \%(103.0 \mathrm{mg})$ yield.

${ }^{1} \mathrm{H}$ NMR (600 MHz, DMSO- $\left.d_{6}\right): \delta 11.51(\mathrm{~s}, 1 \mathrm{H}, \mathrm{NH}$ uracil), 7.90 $\left(\mathrm{s}, 1 \mathrm{H}, \mathrm{H}-6\right.$ uracil), $5.06\left(\mathrm{~d}, J_{\mathrm{H}, \mathrm{H}}=5.4 \mathrm{~Hz}, 1 \mathrm{H}, 2^{\prime}-\mathrm{OH}\right), 4.70\left(\mathrm{t}, J_{\mathrm{H}, \mathrm{H}}=\right.$ $\left.5.4 \mathrm{~Hz}, 1 \mathrm{H}, 3^{\prime}-\mathrm{OH}\right), 4.50\left(\mathrm{pt}, J_{\mathrm{H}, \mathrm{H}}=1.8 \mathrm{~Hz}, 2 \mathrm{H}, \mathrm{C}_{5} \mathrm{H}_{4}\right), 4.30\left(\mathrm{pt}, J_{\mathrm{H}, \mathrm{H}}\right.$ $\left.=1.8 \mathrm{~Hz}, 2 \mathrm{H}, \mathrm{C}_{5} \mathrm{H}_{4}\right), 4.26\left(\mathrm{~s}, 5 \mathrm{H}, \mathrm{C}_{5} \mathrm{H}_{5}\right), 3.97\left(\mathrm{dd}, J_{\mathrm{H}, \mathrm{H}}=13.8,3.6\right.$ $\left.\mathrm{Hz}, 1 \mathrm{H}, 1^{\prime}-\mathrm{CH}_{2}\right), 3.70\left(\mathrm{~m}, 1 \mathrm{H}, 2^{\prime}-\mathrm{CH}\right), 3.45\left(\mathrm{dd}, J_{\mathrm{H}, \mathrm{H}}=13.8,9.0 \mathrm{~Hz}\right.$, $\left.1 \mathrm{H}, 1^{\prime}-\mathrm{CH}_{2}\right), 3.39\left(\mathrm{dt}, J_{\mathrm{H}, \mathrm{H}}=10.8,5.4 \mathrm{~Hz}, 1 \mathrm{H}, 3^{\prime}-\mathrm{CH}_{2}\right), 3.31\left(\mathrm{dt}, J_{\mathrm{H}, \mathrm{H}}\right.$ $\left.=10.8,5.4 \mathrm{~Hz}, 1 \mathrm{H}, 33^{\prime}-\mathrm{CH}_{2}\right)$ ppm. ${ }^{13} \mathrm{C}\left\{{ }^{1} \mathrm{H}\right\}$ NMR $(150 \mathrm{MHz}$, DMSO$\left.d_{6}\right): \delta 162.1,150.0,149.5,97.2,90.5,78.0,70.98,70.96,69.7,68.8$, 68.7, 64.5, 63.6, $51.5 \mathrm{ppm}$. MS (EI, $70 \mathrm{eV}): m / z 394\left(\mathrm{M}^{+}\right)$. FTIR $\left(\mathrm{KBr} \nu\left[\mathrm{cm}^{-1}\right]\right): 3455,3388,3157,3102,3041,2949,2808,1736$ $(\mathrm{C}=\mathrm{O}), 1697(\mathrm{C}=\mathrm{O}), 1666(\mathrm{C}=\mathrm{O}), 1441,1105,1033$. Anal. Calcd for $\mathrm{C}_{19} \mathrm{H}_{18} \mathrm{~N}_{2} \mathrm{O}_{4} \mathrm{Fe}$ : C, 57.89; $\mathrm{H}, 4.60 ; \mathrm{N}, 7.11$. Found: $\mathrm{C}$, 57.64; H, 4.74; N, 7.25.

Synthesis of 5. A solution of 4,4'-dimethoxytrityl chloride (81 $\mathrm{mg}, 0.24 \mathrm{mmol}, 1.2$ equiv) in dry dichloromethane $(240 \mu \mathrm{L})$ was added dropwise to a stirred solution of $4(80 \mathrm{mg}, 0.20 \mathrm{mmol}, 1.0$ equiv) in dry pyridine $(2 \mathrm{~mL})$. The resulting reaction mixture was stirred at ambient temperature overnight. Subsequently, all volatiles were removed under reduced pressure, and the residue was dissolved in dichloromethane $(30 \mathrm{~mL})$ and extracted with saturated $\mathrm{NaHCO}_{3}$ solution $(3 \times 20 \mathrm{~mL})$ and brine $(1 \times 20 \mathrm{~mL})$. The organic layer was separated in a separation funnel, dried over anhydrous $\mathrm{Na}_{2} \mathrm{SO}_{4}$, and filtered through a Schott funnel, and all volatile materials were then evaporated. The residue was subjected to column chromatography on $\mathrm{SiO}_{2}$ ( $n$-hexane/EtOAc $2 / 1$ to $\left.1 / 1 \mathrm{v} / \mathrm{v}\right)$. Chromatographically purified 5 was crystallized from a dichloromethane $/ n$-hexane mixture to afford an analytically pure sample as an orange crystalline solid in $72 \%(100 \mathrm{mg})$ yield.

${ }^{1} \mathrm{H}$ NMR (600 MHz, DMSO- $\left.d_{6}\right): \delta 11.56(\mathrm{~s}, 1 \mathrm{H}, \mathrm{NH}$ uracil), 7.90 (s, 1H, H-6 uracil), $7.43\left(\mathrm{~d}, J_{\mathrm{H}, \mathrm{H}}=7.2 \mathrm{~Hz}, 2 \mathrm{H}, \mathrm{DMTr}\right), 7.29(\mathrm{~m}, 6 \mathrm{H}$, $\mathrm{DMTr}), 7.22\left(\mathrm{t}, J_{\mathrm{H}, \mathrm{H}}=7.2 \mathrm{~Hz}, 1 \mathrm{H}, \mathrm{DMTr}\right), 6.89\left(\mathrm{dt}, J_{\mathrm{H}, \mathrm{H}}=9.6,2.4\right.$ $\mathrm{Hz}, 4 \mathrm{H}, \mathrm{DMTr}), 5.33\left(\mathrm{~d}, J_{\mathrm{H}, \mathrm{H}}=6.0 \mathrm{~Hz}, 1 \mathrm{H}, 2-\mathrm{OH}\right), 4.48\left(\mathrm{pt}, J_{\mathrm{H}, \mathrm{H}}=\right.$ $\left.1.8 \mathrm{~Hz}, 2 \mathrm{H}, \mathrm{C}_{5} \mathrm{H}_{4}\right), 4.30\left(\mathrm{pt}, J_{\mathrm{H}, \mathrm{H}}=1.8 \mathrm{~Hz}, 2 \mathrm{H}, \mathrm{C}_{5} \mathrm{H}_{4}\right), 4.24(\mathrm{~s}, 5 \mathrm{H}$, $\left.\mathrm{C}_{5} \mathrm{H}_{5}\right), 3.99\left(\mathrm{dd}, J_{\mathrm{H}, \mathrm{H}}=13.5,3.6 \mathrm{~Hz}, 1 \mathrm{H}, 1^{\prime}-\mathrm{CH}_{2}\right), 3.93\left(\mathrm{~m}, 1 \mathrm{H}, 2^{\prime}-\right.$ $\mathrm{CH}), 3.73\left(\mathrm{~s}, 6 \mathrm{H}, 2 \times \mathrm{CH}_{3}\right), 3.58\left(\mathrm{dd}, J_{\mathrm{H}, \mathrm{H}}=13.2,8.4 \mathrm{~Hz}, 1 \mathrm{H}, \mathrm{l}^{\prime}\right.$ $\left.\mathrm{CH}_{2}\right), 2.95\left(\mathrm{dd}, J_{\mathrm{H}, \mathrm{H}}=9.3,5.4 \mathrm{~Hz}, 1 \mathrm{H}, 3^{\prime}-\mathrm{CH}_{2}\right), 2.88\left(\mathrm{dd}, J_{\mathrm{H}, \mathrm{H}}=9.3\right.$, $\left.5.4 \mathrm{~Hz}, 1 \mathrm{H}, 3^{\prime}-\mathrm{CH}_{2}\right) .{ }^{13} \mathrm{C}\left\{{ }^{1} \mathrm{H}\right\}$ NMR $\left(150 \mathrm{MHz}\right.$, DMSO- $\left.d_{6}\right): \delta 162.1$, $158.0,150.0,149.3,144.9,135.6,129.6,127.8,127.6,126.6,113.1$, 
97.3, 90.6, 85.3, 78.0, 70.9, 69.7, 68.8, 66.9, 65.5, 64.5, 55.0, 51.6 ppm. MS (ESI-): $m / z 695\left(\mathrm{M}^{-}\right)$. FTIR $\left(\mathrm{KBr} \nu\left[\mathrm{cm}^{-1}\right]\right): 3168,3032,2925$, 2855, 2833, $1717(\mathrm{C}=\mathrm{O}), 1699(\mathrm{C}=\mathrm{O}), 1683(\mathrm{C}=\mathrm{O}), 1507,1446$, 1247. Anal. Calcd for $\mathrm{C}_{40} \mathrm{H}_{36} \mathrm{~N}_{2} \mathrm{O}_{6} \mathrm{Fe}$ : C, 68.97; H, 5.21; N, 4.02. Found: C, 68.77; H, 5.44; N, 4.01.

Synthesis of 6 . To a stirred solution of $5(71 \mathrm{mg}, 0.10 \mathrm{mmol}, 1.0$ equiv) in dry dichloromethane $(400 \mu \mathrm{L})$ were added DCI $(8 \mathrm{mg}, 0.07$ mmol, 0.7 equiv) in dry acetonitrile $(100 \mu \mathrm{L})$ and 2 -cyanoethyl $N, N, N^{\prime}, N^{\prime}$-tetraisopropylphosphorodiamidite $(32 \mu \mathrm{L}, 0.100 \mathrm{mmol}$, 1.0 equiv). After $3 \mathrm{~h}$, the reaction mixture was diluted with dichloromethane $(10 \mathrm{~mL})$ and extracted with a saturated water solution of $\mathrm{NaHCO}_{3}(30 \mathrm{~mL})$ and brine $(15 \mathrm{~mL})$. The organic layer was separated in a separation funnel, dried over anhydrous $\mathrm{Na}_{2} \mathrm{SO}_{4}$, and filtered through a Schott funnel, and all volatile materials were then evaporated. The residue was subjected to column chromatography on $\mathrm{SiO}_{2}$ ( $n$-hexane/EtOAc, $3 / 1$ to $2 / 1 \mathrm{v} / \mathrm{v}$ ). Chromatographically purified 6 was crystallized from a dichloromethane $/ n$ hexane mixture to afford an analytically pure sample as an orange crystalline solid in $67 \%(60.0 \mathrm{mg})$ yield.

${ }^{31} \mathrm{P}$ NMR (243 MHz, DMSO-d $): \delta 148.9,148.4 \mathrm{ppm}$. HRMS (ESI + ): $m / z$ 897.3101 (calcd for $\mathrm{C}_{49} \mathrm{H}_{54} \mathrm{~N}_{4} \mathrm{O}_{7} \mathrm{PFe}: 897.3080$ ). FTIR ( $\mathrm{KBr}$ $\left.\nu\left[\mathrm{cm}^{-1}\right]\right): 3183,3059,2966,2931,2871,2835,2251(\mathrm{CN}), 2223$ $(\mathrm{CN}), 1698(\mathrm{C}=\mathrm{O}), 1607(\mathrm{C}=\mathrm{O}), 1508,1445,1250,1178,1031$, $827,581$.

Synthesis of 7. A deoxygenated mixture of $1(380 \mathrm{mg}, 0.83 \mathrm{mmol}$, 1.0 equiv), ethynylferrocene (523 mg, $2.490 \mathrm{mmol}, 3.0$ equiv), triphenylphosphine $(21 \mathrm{mg}, 0.080 \mathrm{mmol}, 0.1$ equiv), triethylamine $(231 \mu \mathrm{L}, 1.660 \mathrm{mmol}, 2.0$ equiv), copper(I) iodide (316 mg, 1.660 mmol, 2.0 equiv), and tetrakis(triphenylphosphane)palladium(0) (92 $\mathrm{mg}, 0.080 \mathrm{mmol}, 0.1$ equiv) in DMF $(4 \mathrm{~mL})$ was stirred at ambient temperature overnight. All volatile materials were evaporated under reduced pressure. The residue was subjected to column chromatography on $\mathrm{SiO}_{2}$ ( $n$-hexane/EtOAc; $\left.1 / 1 \mathrm{v} / \mathrm{v}\right)$. Chromatographically purified 7 was crystallized from a dichloromethane $/ n$-hexane mixture to afford an analytically pure sample as an orange crystalline solid in $62 \%(278 \mathrm{mg})$ yield.

${ }^{1} \mathrm{H}$ NMR (600 MHz, DMSO- $d_{6}$ ): $\delta 8.28$ (s, $1 \mathrm{H}, \mathrm{H}-6$ uracil), 8.03 $\left(\mathrm{d}, J_{\mathrm{H}, \mathrm{H}}=7.8 \mathrm{~Hz}, 2 \mathrm{H}, o-\mathrm{H}\right.$ benzoyl), $7.81\left(\mathrm{t}, J_{\mathrm{H}, \mathrm{H}}=7.8 \mathrm{~Hz}, 1 \mathrm{H}, p-\mathrm{H}\right.$ benzoyl), $7.62\left(\mathrm{t}, J_{\mathrm{H}, \mathrm{H}}=7.8 \mathrm{~Hz}, 2 \mathrm{H}, m-\mathrm{H}\right.$ benzoyl $), 4.52\left(\mathrm{pt}, J_{\mathrm{H}, \mathrm{H}}=\right.$ $\left.1.8 \mathrm{~Hz}, 2 \mathrm{H}, \mathrm{C}_{5} \mathrm{H}_{4}\right), 4.38\left(\mathrm{~m}, 1 \mathrm{H}, 2^{\prime}-\mathrm{CH}\right), 4.32\left(\mathrm{pt}, J_{\mathrm{H}, \mathrm{H}}=1.8 \mathrm{~Hz}, 2 \mathrm{H}\right.$, $\left.\mathrm{C}_{5} \mathrm{H}_{4}\right), 4.25\left(\mathrm{~s}, 5 \mathrm{H}, \mathrm{C}_{5} \mathrm{H}_{5}\right), 4.04\left(\mathrm{dd}, J_{\mathrm{H}, \mathrm{H}}=9.0,6.6 \mathrm{~Hz}, 1 \mathrm{H}, \mathrm{1}^{\prime}-\mathrm{CH}_{2}\right)$, $3.93\left(\mathrm{~m}, 2 \mathrm{H}, 3^{\prime}-\mathrm{CH}_{2}\right) 3.75\left(\mathrm{dd}, J_{\mathrm{H}, \mathrm{H}}=9.0,4.8 \mathrm{~Hz}, 1 \mathrm{H}, 1^{\prime}-\mathrm{CH}_{2}\right), 1.38$ $\left(\mathrm{s}, 3 \mathrm{H}, \mathrm{CH}_{3}\right), 1.28\left(\mathrm{~s}, 3 \mathrm{H}, \mathrm{CH}_{3}\right)$ ppm. ${ }^{13} \mathrm{C}\left\{{ }^{1} \mathrm{H}\right\} \mathrm{NMR}(150 \mathrm{MHz}$, DMSO- $\left.d_{6}\right): \delta 168.7,160.7,149.4,148.8,135.7,130.7,130.4,129.5$, 109.0, 98.0, 92.1, 76.5, 72.9, 71.1, 69.8, 69.0, 66.0, 63.8, 50.5, 26.5, $25.1 \mathrm{ppm}$. MS (EI): $m / z 538\left(\mathrm{M}^{+}\right)$. FTIR $\left(\mathrm{KBr} \nu\left[\mathrm{cm}^{-1}\right]\right): 3085$, 2983, 2931, 1751 ( $=\mathrm{O}), 1705(\mathrm{C}=\mathrm{O}), 1667(\mathrm{C}=\mathrm{O}), 1626,1428$, 1379, 1238. Anal. Calcd for $\mathrm{C}_{29} \mathrm{H}_{26} \mathrm{~N}_{2} \mathrm{O}_{5} \mathrm{Fe}$ : C, 64.70; H, 4.87; N, 5.20. Found: C, $64.60 ; \mathrm{H}, 4.85$; N, 5.30.

Synthesis of 8 and 3. Hydrochloric acid $(1.0 \mathrm{M}, 6 \mathrm{~mL})$ was added in a single portion to a stirred solution of $7(218 \mathrm{mg}, 0.40$ mmol, 1.0 equiv $)$ in THF $(6 \mathrm{~mL})$. The reaction mixture was stirred at ambient temperature for $6 \mathrm{~h}$. Then, $5 \% \mathrm{NaHCO}_{3}(\sim 1.1 \mathrm{~mL})$ was added, and the reaction mixture was extracted with dichloromethane. The organic layer was separated in a separation funnel, dried over anhydrous $\mathrm{Na}_{2} \mathrm{SO}_{4}$, and filtered through a Schott funnel, and all volatiles were evaporated under reduced pressure. The remaining solid was subjected to column chromatography on $\mathrm{SiO}_{2}$ with $\mathrm{DCM}$ / $\mathrm{MeOH}(10 / 1 \mathrm{v} / \mathrm{v})$ as the eluent mixture. Two fractions were collected. The first fraction contained compound 3 , and the second contained compound 8. Crystallization from a dichloromethane $/ n$ hexane mixture afforded analytically pure samples. Compound 3 was obtained as an orange crystalline solid in $26 \%(52 \mathrm{mg})$ yield, and compound 8 was obtained as an orange-red crystalline solid in 59\% (93 mg) yield.

Synthesis of 8. Trifluoroacetic acid $(11 \mu \mathrm{L}, 0.140 \mathrm{mmol}, 1.1$ equiv) was added dropwise to a stirred solution of $7(50 \mathrm{mg}, 0.13$ mmol, 1.0 equiv) in dichloromethane $(4 \mathrm{~mL})$. The reaction mixture was stirred at ambient temperature for $30 \mathrm{~min}$. Then, $5 \% \mathrm{NaHCO}_{3}$ $(\sim 5 \mathrm{~mL})$ was added, and the reaction mixture was extracted with dichloromethane. The organic layer was separated in a separation funnel, dried over anhydrous $\mathrm{Na}_{2} \mathrm{SO}_{4}$, and filtered through a Schott funnel, and all volatiles were evaporated under reduced pressure. The remaining solid was subjected to column chromatography on $\mathrm{SiO}_{2}$ with $\mathrm{DCM} / \mathrm{MeOH}(10 / 1 \mathrm{v} / \mathrm{v})$ as the eluent mixture. Crystallization from a dichloromethane $/ n$-hexane mixture afforded compound $\mathbf{8}$ as an orange-red crystalline solid in $96 \%$ (48 $\mathrm{mg}$ ) yield.

${ }^{1} \mathrm{H}$ NMR (600 MHz, DMSO- $d_{6}$ ): $\delta 8.33$ (s, 1H, H-6 uracil), 6.74 (s, $1 \mathrm{H}, \mathrm{H}$-dihydrofuran), $4.81\left(\mathrm{~s}, J_{\mathrm{H}, \mathrm{H}}=1.8 \mathrm{~Hz}, 1 \mathrm{H}, \mathrm{C}_{5} \mathrm{H}_{4}\right), 4.78(\mathrm{pt}$, $\left.J_{\mathrm{H}, \mathrm{H}}=6.0 \mathrm{~Hz}, 1 \mathrm{H}, \mathrm{C}_{5} \mathrm{H}_{4}\right), 4.46\left(\mathrm{pt}, J_{\mathrm{H}, \mathrm{H}}=1.8 \mathrm{~Hz}, 2 \mathrm{H}, \mathrm{C}_{5} \mathrm{H}_{4}\right), 4.28$ $\left(\mathrm{dd}, J_{\mathrm{H}, \mathrm{H}}=12.9,3.6 \mathrm{~Hz}, 1 \mathrm{H}, \mathrm{l}^{\prime}-\mathrm{CH}_{2}\right), 4.16\left(\mathrm{~s}, 5 \mathrm{H}, \mathrm{C}_{5} \mathrm{H}_{5}\right), 3.80(\mathrm{~m}$, $\left.1 \mathrm{H}, 2^{\prime}-\mathrm{CH}\right), 3.59\left(\mathrm{dd}, J_{\mathrm{H}, \mathrm{H}}=12.9,9.0 \mathrm{~Hz}, 1 \mathrm{H}, 1^{\prime}-\mathrm{CH}_{2}\right), 3.43(\mathrm{~m}, 1 \mathrm{H}$, $\left.3^{\prime}-\mathrm{CH}_{2}\right), 3.36\left(\mathrm{~m}, 1 \mathrm{H}, 3^{\prime}-\mathrm{CH}_{2}\right)$ ppm. ${ }^{13} \mathrm{C}\left\{{ }^{1} \mathrm{H}\right\}$ NMR $(150 \mathrm{MHz}$, DMSO- $\left.d_{6}\right): \delta 171.1,155.0,154.7,142.6,106.5,96.5,73.0,69.7,69.5$, 68.4, 66.0, 63.7, 54.5 ppm. MS (EI): $m / z 394\left(\mathrm{M}^{+}\right)$. FTIR (KBr $\nu$ $\left.\left[\mathrm{cm}^{-1}\right]\right): 3314(\mathrm{OH}), 3088,3024,2948,1669,1617,1575,1559$, 1411, 1378, 1105, 777. Anal. Calcd for $\mathrm{C}_{19} \mathrm{H}_{18} \mathrm{~N}_{2} \mathrm{O}_{4} \mathrm{Fe}$ : C, 57.89; $\mathrm{H}$, 4.60; N, 7.11. Found: C, 57.75; H, 4.84; N, 7.08.

Synthesis of 9. A $0.45 \mathrm{M}$ tetrazole solution $(4.3 \mathrm{~mL}, 1.92 \mathrm{mmol}$, 4.0 equiv) was added at ambient temperature to a stirred solution of $\mathrm{N}^{6}$-benzoyl-2',3'-O-isopropylideneadenosine (197 mg, $0.48 \mathrm{mmol}, 1.0$ equiv) in dry acetonitrile $(1 \mathrm{~mL})$. The resulting mixture was cooled to $0{ }^{\circ} \mathrm{C}$, and subsequently, a solution of phosphoramidite $6(567 \mathrm{mg}$, $0.63 \mathrm{mmol}, 1.3$ equiv) in dry acetonitrile $(1.5 \mathrm{~mL})$ was added dropwise and the reaction mixture was stirred for $15 \mathrm{~min}$ at $0{ }^{\circ} \mathrm{C}$. The reaction mixture was then allowed to warmed to ambient temperature, and the stirring was continued for $30 \mathrm{~min}$. The reaction mixture was cooled again to $0{ }^{\circ} \mathrm{C}$, and a $0.1 \mathrm{M}$ iodine solution $(4.8 \mathrm{~mL}, 0.48$ mmol, 1.0 equiv $)$ in water/pyridine/THF $(1 / 10 / 40 \mathrm{v} / \mathrm{v})$ mixture was added dropwise for $30 \mathrm{~min}$. The reaction mixture was stirred for 10 min at $0{ }^{\circ} \mathrm{C}$ and for an additional $15 \mathrm{~min}$ at ambient temperature. All volatiles were then evaporated under reduced pressure, and the residue was dissolved in ethyl acetate $(50 \mathrm{~mL})$ and washed with $10 \%$ sodium thiosulfate $(3 \times 15 \mathrm{~mL})$ and water $(1 \times 25 \mathrm{~mL})$. The organic layer was separated in a separation funnel, dried over anhydrous $\mathrm{Na}_{2} \mathrm{SO}_{4}$, filtered through a Schott funnel, and evaporated to dryness. The remaining material was subjected to column chromatography on $\mathrm{SiO}_{2}$ with $\mathrm{DCM} / \mathrm{MeOH}(50 / 1 \mathrm{v} / \mathrm{v})$ as the eluent mixture. After evaporation of the eluent mixture, the 2-cyanoethoxy intermediate INT was obtained as an orange solid $(592 \mathrm{mg}, 0.48 \mathrm{mmol})$. It was dissolved in $10 \mathrm{~mL}$ of a $25 \% \mathrm{NH}_{3, \mathrm{aq}} / 40 \% \mathrm{NMe}_{3, \mathrm{aq}}(1 / 1 \mathrm{v} / \mathrm{v})$ mixture at ambient temperature. The resulting reaction mixture was stirred for $1 \mathrm{~h}$ at $50{ }^{\circ} \mathrm{C}$, and all volatiles were evaporated under reduced pressure. The remaining material was dissolved in $50 \mathrm{~mL}$ of a DCM/MeOH $(20 / 1 \mathrm{v} / \mathrm{v})$ mixture and washed with $0.2 \mathrm{M} \mathrm{HCl}(2 \times 25 \mathrm{~mL})$ and water $(1 \times 50 \mathrm{~mL})$. The organic layer was separated in a separation funnel, dried over anhydrous $\mathrm{Na}_{2} \mathrm{SO}_{4}$, filtered through a Schott funnel, and evaporated to dryness. The remaining solid was subjected to preparative TLC with $\mathrm{DCM} / \mathrm{MeOH}(5 / 1 \mathrm{v} / \mathrm{v})$ as the eluent mixture. Dinucleoside phosphate 9 was obtained as an orange solid in $47 \%$ (242 mg) yield.

${ }^{1} \mathrm{H}$ NMR (600 MHz, DMSO- $\left.d_{6}\right): \delta 11.42(\mathrm{~s}, 1 \mathrm{H}, \mathrm{NH}$ uracil), 8.49 (s, 1H, H-8 adenine), 8.12 (s, 1H, H-2 adenine), 7.94 (s, 1H, H-6 uracil), 7.41 (d, $\left.J_{\mathrm{H}, \mathrm{H}}=7.8 \mathrm{~Hz}, 2 \mathrm{H}, \mathrm{DMTr}\right), 7.29(\mathrm{~m}, 6 \mathrm{H}, \mathrm{DMTr})$, $7.24\left(\mathrm{~s}, 2 \mathrm{H}, \mathrm{NH}_{2}\right.$ adenine), $7.16\left(\mathrm{t}, J_{\mathrm{H}, \mathrm{H}}=7.8 \mathrm{~Hz}, 1 \mathrm{H}, \mathrm{DMTr}\right), 6.82$ (dd, $\left.J_{\mathrm{H}, \mathrm{H}}=9.0,6.6 \mathrm{~Hz}, 4 \mathrm{H}, \mathrm{DMTr}\right), 6.09$ (d, 1H, $1^{\prime}-\mathrm{CH}$ ribose), 5.26 $\left(\mathrm{dd}, J_{\mathrm{H}, \mathrm{H}}=6.0,3.6 \mathrm{~Hz}, 1 \mathrm{H}, 2^{\prime}-\mathrm{CH}\right.$ ribose $), 4.95\left(\mathrm{dd}, J_{\mathrm{H}, \mathrm{H}}=6.0,1.8\right.$ $\mathrm{Hz}, 1 \mathrm{H}, 3^{\prime}-\mathrm{CH}$ ribose), $4.44\left(\mathrm{pt}, J_{\mathrm{H}, \mathrm{H}}=1.8 \mathrm{~Hz}, 2 \mathrm{H}, \mathrm{C}_{5} \mathrm{H}_{4}\right), 4.40(\mathrm{~m}$, $1 \mathrm{H}, 2^{\prime}-\mathrm{CH}$ GNA), 4.27 (pt, $\left.J_{\mathrm{H}, \mathrm{H}}=1.8 \mathrm{~Hz}, 2 \mathrm{H}, \mathrm{C}_{5} \mathrm{H}_{4}\right), 4.22(\mathrm{~s}, 5 \mathrm{H}$, $\left.\mathrm{C}_{5} \mathrm{H}_{5}\right), 4.11\left(\mathrm{q}, J_{\mathrm{H}, \mathrm{H}}=5.4 \mathrm{~Hz}, 1 \mathrm{H}, 4^{\prime}-\mathrm{CH}\right.$ ribose $), 3.99\left(\mathrm{dd}, J_{\mathrm{H}, \mathrm{H}}=\right.$ 13.2, 3.6 Hz, $1 \mathrm{H}, 1^{\prime}-\mathrm{CH}_{2} \mathrm{GNA}$ ), $3.87\left(\mathrm{dd}, J_{\mathrm{H}, \mathrm{H}}=13.5,7.8 \mathrm{~Hz}, 1 \mathrm{H}, 1^{\prime}-\right.$ $\mathrm{CH}_{2}$ GNA), $3.69\left(\mathrm{~s}, 3 \mathrm{H}, \mathrm{OCH}_{3}\right), 3.68\left(\mathrm{~s}, 3 \mathrm{H}, \mathrm{OCH}_{3}\right), 3.16\left(\mathrm{~d}, J_{\mathrm{H}, \mathrm{H}}=\right.$ $5.4 \mathrm{~Hz}, 2 \mathrm{H}, 5^{\prime}-\mathrm{CH}_{2}$ ribose), $3.02\left(\mathrm{dd}, \mathrm{J}_{\mathrm{H}, \mathrm{H}}=9.0,5.4 \mathrm{~Hz}, 1 \mathrm{H}, 3^{\prime}-\mathrm{CH}_{2}\right.$ GNA), 2.90 (bs, $\left.1 \mathrm{H}, 3^{\prime}-\mathrm{CH}_{2} \mathrm{GNA}\right), 1.52\left(\mathrm{~s}, 3 \mathrm{H}, \mathrm{CH}_{3}\right), 1.28(\mathrm{~s}, 3 \mathrm{H}$, $\left.\mathrm{CH}_{3}\right) .{ }^{13} \mathrm{C}\left\{{ }^{1} \mathrm{H}\right\}$ NMR $(150 \mathrm{MHz}$, DMSO-d 6 ): $\delta 157.9,156.0,152.7$, 149.2 , 149.1, 144.8, 139.5, 135.7, 135.6, 129.6, 129.6, 127.7, 127.6, $126.5,118.7,113.0,112.9,97.6,90.4,89.1,85.2,84.7,83.4,81.6,70.9$, $70.8,70.2,69.7,68.7,64.7,64.4,64.1,54.9,50.3,27.1,25.4,25.1 .{ }^{31} \mathrm{P}$ NMR (243 MHz, DMSO- $\left.d_{6}\right): \delta-1.12 \mathrm{ppm}$. MS (ESI-): $\mathrm{m} / z$ 
1064.2670 (calcd for $\mathrm{C}_{53} \mathrm{H}_{51} \mathrm{~N}_{7} \mathrm{O}_{12} \mathrm{PFe}: 1064.2683$ ). FTIR (KBr $\nu$ $\left.\left[\mathrm{cm}^{-1}\right]\right): 2223,1699,1635,1606,1508,1473,1445,1248$.

\section{ASSOCIATED CONTENT}

\section{(3) Supporting Information}

The Supporting Information is available free of charge at https://pubs.acs.org/doi/10.1021/acs.organomet.9b00851.

Spectra $\left({ }^{1} \mathrm{H} /{ }^{13} \mathrm{C} /{ }^{31} \mathrm{P} \mathrm{NMR}\right)$ and crystal data (PDF)

\section{Accession Codes}

CCDC 1962447-1962448 contain the supplementary crystallographic data for this paper. These data can be obtained free of charge via www.ccdc.cam.ac.uk/data_request/cif, or by emailingdata_request@ccdc.cam.ac.uk, or by contacting The Cambridge Crystallographic Data Centre, 12 Union Road, Cambridge CB2 1EZ, UK; fax: +44 1223336033.

\section{AUTHOR INFORMATION}

\section{Corresponding Author}

Konrad Kowalski - Faculty of Chemistry, Department of Organic Chemistry, University of Łódź, 91-403 Łódź, Poland; (1) orcid.org/0000-0003-0600-3205;

Email: konrad.kowalski@chemia.uni.lodz.pl, kondor15@ wp.pl

\section{Authors}

Michal Piotrowicz - Faculty of Chemistry, Department of Organic Chemistry, University of Łódź, 91-403 Łódź, Poland; (1) orcid.org/0000-0001-7214-858X

Aleksandra Kowalczyk - Faculty of Biology and Environmental Protection, Department of Microbial Genetics, University of Łódź, 90-237 Łódź, Poland; ㅇorcid.org/0000-0001-96077173

Damian Trzybiński - Faculty of Chemistry, Biological and Chemical Research Centre, University of Warsaw, 02-089 Warszawa, Poland; 이이이.org/0000-0003-3920-5532

Krzysztof Woźniak - Faculty of Chemistry, Biological and Chemical Research Centre, University of Warsaw, 02-089

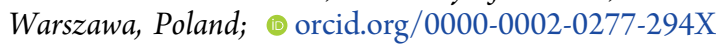

Complete contact information is available at: https://pubs.acs.org/10.1021/acs.organomet.9b00851

\section{Notes}

The authors declare no competing financial interest.

\section{ACKNOWLEDGMENTS}

K.K. thanks the National Science Center in Cracow, Poland (grant OPUS UMO-2018/29/B/ST5/00055), for financial support. Crystallographic measurements were carried out at the Biological and Chemical Research Centre, University of Warsaw, established within the project cofinanced by European Union from the European Regional Development Fund under the Operational Programme Innovative Economy, 2007-2013. The X-ray diffraction data were collected at the Core Facility for Crystallographic and Biophysical Research to support the development of medicinal products sponsored by the Foundation for Polish Science (FNP).

\section{REFERENCES}

(1) Herdewijn, P.; Marlière, P. Toward Safe Genetically Modified Organisms through the Chemical Diversification of Nucleic Acids. Chem. Biodiversity 2009, 6, 791-808.
(2) Chaput, J. C.; Yu, H.; Zhang, S. The Emerging World of Synthetic Genetics. Chem. Biol. 2012, 19, 1360-1371.

(3) Pinheiro, V. B.; Hollinger, P. Towards XNA nanotechnology: new materials from synthetic genetic polymers. Trends Biotechnol. 2014, 32, 321-328.

(4) Ausländer, S.; Ausländer, D.; Fussenegger, M. Synthetic BiologyThe Synthesis of Biology. Angew. Chem., Int. Ed. 2017, 56, 63966419.

(5) Pinheiro, V. B.; Taylor, A. I.; Cozens, C.; Abramov, M.; Renders, M.; Zhang, S.; Chaput, J. C.; Wengel, J.; Peak-Chew, S. Y.; McLaughlin, S. H. Synthetic Genetic Polymers Capable of Heredity and Evolution. Science 2012, 336, 341-344.

(6) Yu, H.; Zhang, S.; Dunn, M.; Chaput, J. C. An Efficient and Faithful in Vitro Replication System for Threose Nucleic Acid. J. Am. Chem. Soc. 2013, 135, 3583-3591.

(7) Chaput, J. C.; Ichida, J. K.; Szostak, J. W. DNA PolymeraseMediated DNA Synthesis on a TNA Template. J. Am. Chem. Soc. 2003, 125, 856-857.

(8) Chaput, J. C.; Szostak, J. W. TNA Synthesis by DNA Polymerases. J. Am. Chem. Soc. 2003, 125, 9274-9275.

(9) Kempeneers, V.; Vastmans, K.; Rozenski, J.; Herdewijn, P. Recognition of threosyl nucleotides by DNA and RNA polymerases. Nucleic Acids Res. 2003, 31, 6221-6226.

(10) Horhota, A.; Zou, K.; Ichida, J. K.; Yu, B.; McLaughlin, L. W.; Szostak, J. W.; Chaput, J. C. Kinetic Analysis of an Efficient DNADependent TNA Polymerase. J. Am. Chem. Soc. 2005, 127, 74277434.

(11) Peng, C. G.; Damha, M. J. Polymerase-Directed Synthesis of 2'Deoxy-2'-fluoro- $\beta$-D-arabinonucleic Acids. J. Am. Chem. Soc. 2007, 129, 5310-5311.

(12) Taylor, A.; Hollinger, P. Directed evolution of artificial enzymes (XNAzymes) from diverse repertoires of synthetic genetic polymers. Nat. Protoc. 2015, 10, 1625-1642.

(13) Yu, H.; Zhang, S.; Chaput, J. C. Darwinian evolution of an alternative genetic system provides support for TNA as an RNA progenitor. Nat. Chem. 2012, 4, 183-187.

(14) Daly, S. M.; Sturge, C. R.; Marshall-Batty, K. R.; Felder-Scott, C. F.; Jain, R.; Geller, B. L.; Greenberg, D. E. Antisense Inhibitors Retain Activity in Pulmonary Models of Burkholderia Infection. ACS Infect. Dis. 2018, 4 (5), 806-814.

(15) Meggers, E.; Zhang, L. Synthesis and Properties of the Simplified Nucleic Acid Glycol Nucleic Acid. Acc. Chem. Res. 2010, 43, $1092-1102$.

(16) Anosova, I.; Kowal, E. A.; Dunn, M. R.; Chaput, J. C.; Van Horn, W. D.; Egli, M. The structural diversity of artificial genetic polymers. Nucleic Acids Res. 2016, 44, 1007-1021.

(17) Ueda, N.; Kawabata, T.; Takemoto, K. Synthesis of N-(2,3dihydroxypropyl) derivatives of nucleic bases. J. Heterocycl. Chem. 1971, 8, 827-829.

(18) Seita, T.; Yamauchi, K.; Kinoshita, M.; Imoto, M. The Synthesis of Nucleoside and Nucleotide Analogs. Bull. Chem. Soc. Jpn. 1972, 45, 926-928.

(19) Seita, T.; Kinoshita, M.; Imoto, M. Synthesis of Some Substituted Nucleoside Analogs. Bull. Chem. Soc. Jpn. 1973, 46, $1572-1573$.

(20) Seita, T.; Yamauchi, K.; Kinoshita, M.; Imoto, M. Condensation polymerization of nucleotide analogues. Makromol. Chem. 1972, 154, 255-261.

(21) Holý, A.; Ivanova, G. S. Aliphatic analogues of nucleotides: synthesis and affinity towards nucleases. Nucleic Acids Res. 1974, 1, $19-34$.

(22) Holý, A. Aliphatic analogues of nucleosides, nucleotides, and oligonucleotides. Collect. Czech. Chem. Commun. 1975, 40, 187-214.

(23) Cook, P. D.; Acevedo, O. L.; Davis, P. W.; Ecker, D. J.; Normand, H. Phosphate linked oligomers. U.S. Patent5886177, 1999.

(24) Acevedo, O. L.; Andrews, R. S. Synthesis of propane-2,3-diol combinatorial monomers. Tetrahedron Lett. 1996, 37, 3931-3934.

(25) Nielsen, P.; Dreiøe, L. H.; Wengel, J. Synthesis and evaluation of oligodeoxynucleotides containing acyclic nucleosides: Introduction 
of three novel analogues and a summary. Bioorg. Med. Chem. 1995, 3, $19-28$.

(26) Zhang, L.; Peritz, A.; Meggers, E. A Simple Glycol Nucleic Acid. J. Am. Chem. Soc. 2005, 127, 4174-4175.

(27) Zhang, L.; Peritz, A. E.; Carroll, P. J.; Meggers, E. Synthesis of Glycol Nucleic Acids. Synthesis 2006, 2006, 645-653.

(28) Schlegel, M. K.; Meggers, E. Improved Phosphoramidite Building Blocks for the Synthesis of the Simplified Nucleic Acid GNA. J. Org. Chem. 2009, 74, 4615-4618.

(29) Schlegel, M. K.; Xie, X.; Zhang, L.; Meggers, E. Insight into the High Duplex Stability of the Simplified Nucleic Acid GNA. Angew. Chem., Int. Ed. 2009, 48, 960-963.

(30) Schlegel, M. K.; Peritz, A. E.; Kittigowittana, K.; Zhang, L.; Meggers, E. Duplex Formation of the Simplified Nucleic Acid GNA. ChemBioChem 2007, 8, 927-932.

(31) Schlegel, M. K.; Essen, L.-O.; Meggers, E. Duplex Structure of a Minimal Nucleic Acid. J. Am. Chem. Soc. 2008, 130, 8158-8159.

(32) Schlegel, M. K.; Essen, L.-O.; Meggers, E. Atomic resolution duplex structure of the simplified nucleic acid GNA. Chem. Commun. 2010, 46, 1094-1096.

(33) Declercq, R.; Van Aerschot, A.; Read, R. J.; Herdewijn, P.; Van Meervelt, L. Crystal Structure of Double Helical Hexitol Nucleic Acids. J. Am. Chem. Soc. 2002, 124, 928-933.

(34) Egli, M.; Pallan, P. S.; Pattanayek, R.; Wilds, C. J.; Lubini, P.; Minasov, G.; Dobler, M.; Leumann, C. J.; Eschenmoser, A. Crystal Structure of Homo-DNA and Nature's Choice of Pentose over Hexose in the Genetic System. J. Am. Chem. Soc. 2006, 128, 1084710856.

(35) Zhang, R. S.; McCullum, E. O.; Chaput, J. C. Synthesis of Two Mirror Image 4-Helix Junctions Derived from Glycerol Nucleic Acid. J. Am. Chem. Soc. 2008, 130, 5846-5847.

(36) Hakala, H.; Ollikka, P.; Degerholm, J.; Hovinen, J. Oligonucleotide conjugates based on acyclonucleosides and their use in DNA hybridization assays. Tetrahedron 2002, 58, 8771-8777.

(37) Chen, J. J.; Cai, X.; Szostak, J. W. N2'-P3' Phosphoramidate Glycerol Nucleic Acid as a Potential Alternative Genetic System. J. Am. Chem. Soc. 2009, 131, 2119-2121.

(38) Kaiser, M. M.; Novák, P.; Rosenbergová, Š.; PoštováSlavětínská, L.; Rosenberg, I.; Janeba, Z. Acyclic Nucleoside Phosphonates Bearing $(R)$ - or $(S)$-9-[3-Hydroxy-2(phosphonoethoxy)propyl] (HPEP) Moiety as Monomers for the Synthesis of Modified Oligonucleotides. Eur. J. Org. Chem. 2018, 2018, 5119-5126.

(39) Larsen, E.; Danel, K.; Pedersen, E. B. Synthesis of a Carboxamide Linked $\mathrm{T}^{*} \mathrm{~T}$ Dimer with an Acyclic Nucleoside Unit and Its Incorporation in Oligodeoxynucleotides. Nucleosides Nucleotides 1995, 14, 1905-1912.

(40) Kowalski, K. Ferrocenyl-nucleobase complexes: Synthesis, chemistry and applications. Coord. Chem. Rev. 2016, 317, 132-156.

(41) Toma, M.; Božičević, L.; Lapić, J.; Djaković, S.; Šakić, D.; Tandarić, T.; Vianello, R.; Vrček, V. Transacylation in FerrocenoylPurines. NMR and Computational Study of the Isomerization Mechanism. J. Org. Chem. 2019, 84, 12471-12480.

(42) Kowalski, K.; Skiba, J.; Oehninger, L.; Ott, I.; Solecka, J.; Rajnisz, A.; Therrien, B. Metallocene-Modified Uracils: Synthesis, Structure, and Biological Activity. Organometallics 2013, 32, 57665773.

(43) Skiba, J.; Karpowicz, R.; Szabó, I.; Therrien, B.; Kowalski, K. Synthesis and anticancer activity studies of ferrocenyl-thymine-3,6dihydro- $2 \mathrm{H}$-thiopyranes - A new class of metallocene-nucleobase derivatives. J. Organomet. Chem. 2015, 794, 216-222.

(44) Kedge, J. L.; Nguyen, H. V.; Khan, Z.; Male, L.; Ismail, M. K.; Roberts, H. V.; Hodges, N. J.; Horswell, S. L.; Mehellou, Y.; Tucker, J. H. R. Organometallic Nucleoside Analogues: Effect of Hydroxyalkyl Linker Length on Cancer Cell Line Toxicity. Eur. J. Inorg. Chem. 2017, 2017, 466-476.

(45) Nguyen, H. V.; Sallustrau, A.; Balzarini, J.; Bedford, M. R.; Eden, J. C.; Georgousi, N.; Hodges, N. J.; Kedge, J.; Mehellou, Y.; Tselepis, C.; Tucker, J. H. R. Organometallic Nucleoside Analogues with Ferrocenyl Linker Groups: Synthesis and Cancer Cell Line Studies. J. Med. Chem. 2014, 57, 5817-5822.

(46) Anisimov, I.; Saloman, S.; Hildebrandt, A.; Lang, H.; Trzybiński, D.; Woźniak, K.; Šakić, D.; Vrček, V.; Kowalski, K. 1,1'Bis(thymine)ferrocene Nucleoside: Synthesis and Study of Its Stereoselective Formation. ChemPlusChem 2017, 82, 859-866.

(47) Skiba, J.; Yuan, Q.; Hildebrandt, A.; Lang, H.; Trzybiński, D.; Woźniak, K.; Balogh, R. K.; Gyurcsik, B.; Vrček, V.; Kowalski, K. Ferrocenyl GNA Nucleosides: A Bridge between Organic and Organometallic Xeno-nucleic Acids. ChemPlusChem 2018, 83, 77-86.

(48) Nguyen, H. V.; Zhao, Z. Y.; Sallustrau, A.; Horswell, S. L.; Male, L.; Mulas, A.; Tucker, J. H. R. A ferrocene nucleic acid oligomer as an organometallic structural mimic of DNA. Chem. Commun. 2012, $48,12165-12167$.

(49) Skiba, J.; Schmidt, C.; Lippmann, P.; Ensslen, P.; Wagenknecht, H.-A.; Czerwieniec, R.; Brandl, F.; Ott, I.; Berna acus, T.; Krawczyk, B.; Szczukocki, D.; Kowalski, K. Substitution of Metallocenes with [2.2]Paracyclophane to Enable Confocal Microscopy Imaging in Living Cells. Eur. J. Inorg. Chem. 2017, 2017, 297-305.

(50) Kowalski, K.; Szczupak, Ł.; Saloman, S.; Steverding, D.; Jabłoński, A.; Vrček, V.; Hildebrandt, A.; Lang, H.; Rybarczyk-Pirek, A. Cymantrene, Cyrhetrene and Ferrocene Nucleobase Conjugates: Synthesis, Structure, Computational Study, Electrochemistry and Antitrypanosomal Activity. ChemPlusChem 2017, 82, 303-314.

(51) Skiba, J.; Kowalczyk, A.; Fik, M. A.; Gapińska, M.; Trzybiński, D.; Woźniak, K.; Vrček, V.; Czerwieniec, R.; Kowalski, K. Luminescent pyrenyl-GNA nucleosides: synthesis, photophysics and confocal microscopy studies in cancer HeLa cells. Photochem. Photobiol. Sci. 2019, 18, 2449-2460.

(52) Russ, P.; Schelling, P.; Scapozza, L.; Folkers, G.; Clercq, E. D.; Marquez, V. E. Synthesis and Biological Evaluation of 5-Substituted Derivatives of the Potent Antiherpes Agent (north)-Methanocarbathymine. J. Med. Chem. 2003, 46, 5045-5054.

(53) Ciuk, A. K.; Gloe, T.-E.; Lindhorst, T. K. CarbohydrateScaffolded Thymine Multimers: Scope and Limitations of the Allylation-Hydroboration Sequence. Eur. J. Org. Chem. 2018, 2018, 6971-6982.

(54) Coutouli-Argyropoulou, E.; Tsitabani, M.; Petrantonakis, G.; Terzis, A.; Raptopoulou, C. Labeling of organic biomolecules with ethynylferrocene. Org. Biomol. Chem. 2003, 1, 1382-1388.

(55) Inouye, M.; Ikeda, R.; Takase, M.; Tsuri, T.; Chiba, J. Singlenucleotide Polymorphism Detection with "wire-like" DNA Probes That Display Quasi “on-off” Digital Action. Proc. Natl. Acad. Sci. U. S. A. 2005, 102, 11606-11610.

(56) Fan, C.; Plaxco, K. W.; Heeger, A. J. Electrochemical interrogation of conformational changes as a reagentless method for the sequence-specific detection of DNA. Proc. Natl. Acad. Sci. U. S. A. 2003, 100, 9134-9137.

(57) Anne, A.; Demaille, C. Dynamics of Electron Transport by Elastic Bending of Short DNA Duplexes. Experimental Study and Quantitative Modeling of the Cyclic Voltammetric Behavior of 3'Ferrocenyl DNA End-Grafted on Gold. J. Am. Chem. Soc. 2006, 128, 542-557.

(58) Iurlo, M.; Mengozzi, L.; Rapino, S.; Marcaccio, M.; Perone, R. C.; Masiero, S.; Cozzi, P.; Paolucci, F. New Approaches Toward Ferrocene-Guanine Conjugates: Synthesis and Electrochemical Behavior. Organometallics 2014, 33, 4986-4993.

(59) Electrochemistry; Hamann, C. H., Hamnett, A., Vielstich, W., Eds.; Wiley-VCH: Weinheim, Germany, 2007.

(60) CrysAlis CCD and CrysAlis RED; Oxford Diffraction Ltd: Yarnton, U.K., 2008.

(61) Clark, R. C.; Reid, J. S. The analytical calculation of absorption in multifaceted crystals Acta Cryst. Acta Crystallogr., Sect. A: Found. Crystallogr. 1995, 51, 887-897.

(62) Sheldrick, G. M. Crystal structure refinement with SHELXL. Acta Crystallogr., Sect. C: Struct. Chem. 2015, 71, 3-8.

(63) Spek, A. L. Structure validation in chemical crystallography. Acta Crystallogr., Sect. D: Biol. Crystallogr. 2009, 65, 148-155. 
(64) Dolomanov, O. V.; Bourhis, L. J.; Gildea, R. J.; Howard, J. A. K.; Puschmann, H. OLEX2: A Complete Structure Solution, Refinement and Analysis Program. J. Appl. Crystallogr. 2009, 42, 339-341.

(65) Macrae, C. F.; Bruno, I. J.; Chisholm, J. A.; Edgington, P. R.; McCabe, P.; Pidcock, E.; Rodriguez-Monge, L.; Taylor, R.; van de Streek, J.; Wood, P. A. Mercury CSD 2.0- new features for the visualization and investigation of crystal structures. J. Appl. Crystallogr. 2008, 41, 466-470.

(66) Farrugia, L. J. WinGX and ORTEP for Windows: an update. J. Appl. Crystallogr. 2012, 45, 849-854.

(67) Jabłoński, A.; Kowalczyk, A.; Fik, M. A.; Trzybiński, D.; Woźniak, K.; Vinogradova, K.; Glińska, S.; Vrček, V.; Czerwieniec, R.; Kowalski, K. Anthracene-thymine luminophores: Synthesis, photophysical properties, and imaging in living HeLa cells. Dyes Pigm. 2019, 170, 107554-107565. 